\title{
POLICIES AND PROCEDURES FOR THE TERMINATION OF WAR CONTRACTS
}

\author{
Leon MaLman*
}

\section{INTRODUCTION}

The ABC Corp., which for twenty years has been in the business of manufacturing a variety of metal stampings and machined parts, enters into a contract with the X Ordnance District in March 1943 for the manufacture of 2,500,000 $37 \mathrm{~mm}$. armor piercing shot. The executives of the corporation have figured their price closely and when their offer is accepted they receive a Notice of Award, ${ }^{1}$ signed by a contracting officer. Their attorney advises them that a Notice of Award constitutes a binding agreement with the Government, ${ }^{2}$ so immediately they begin to prepare for the manufacture of the shot. They order materials, some new machine tools, and some special dies and jigs, and as these arrive they begin the laborious process of converting their plant and of getting production under way. While this is going on they receive from the $\mathrm{X}$ Ordnance District their definitive contract $^{3}$ for the $2,500,000$ shot. Their attorney examines it and advises them that it is in order, so the president of the corporation signs it on behalf of the corporation and returns it to the $\mathrm{X}$ Ordnance District. He remembers that the attorney had said something about Article $12^{4}$ providing for cancellation of the contract whenever the Government wishes to do so, but he had looked through the provision, which seemed to state a fair basis of settlement if the contract were cancelled, so he hadn't been very much concerned about the details of the clause. Furthermore, why worry about cancellation? Hadn't the negotiator at the X Ordnance District with whom he had dealt told them that even before this contract was completed they would probably be getting a repeat order?

- A.B., r934, LL.B., 1936, Columbia University. Member, New York Bar. Chief, Legal Unit, Contract Termination Section, Office of the Chief of Ordnance.

I wish to express my gratitude to my friends, Colonel R. Ammi Cutter and Lt. Colonel Harold Shepherd, for their many helpful suggestions and criticisms.

The opinions expressed in this article are, of course, my own and are not in any way to be regarded as the official views of the War Department or any of its services.

${ }^{I}$ Ordnance Procurement Instructions (hereafter cited as OPI) 13,002, C.C.H. War Law Serv. q24, 201.

${ }^{2}$ The Notice of Award is an acceptance of an offer previously made by a prospective contractor.

3 War Department Procurement Regulations (hereafter cited as PR) 1301, CodE OF FED. REg., Title 10, Ch. 8, Part 81, C.C.H. War Law Serv. \{22, 6or.

"This article (hereafter referred to as "the old standard form") is set out in full in Appendix C, infra 514. It formerly appeared in PR 324. 
By September their production line is set up and the production "bugs" have been overcome. Things are humming in the plant and the shot is rolling out. Of course, the Army inspector rejects a lot occasionally but that is to be expected. All they have to worry about now is to get enough materials and enough help and the contract will be completed well within the delivery schedule.

Then, on September 20, it happens. A registered letter arrives from the $X$ Ordnance District. It is a formal notice ${ }^{5}$ terminating the contract. With it come some instructions ${ }^{\dot{B}}$ and a copy of the War Department Termination Accounting Manual for Fixed Price Supply Contracts. ${ }^{7}$ Now the president recalls that cancellation article in the contract. Out it comes, this time for a close and careful reading. It still represents a fair basis of settlement, but the question is: What must the ABC Corp. do in order to get that fair settlement, and quickly, so that it will have sufficient working capital to turn to other work promptly? What about the shot they have in process, the raw materials on hand and on order, the special machine their engineer had devised which had cost them \$rr,000 and of which they had been so proud because it cut down the time for one operation from fifty minutes to seventeen minutes but could be used only for the manufacture of $37 \mathrm{~mm}$. shot? What about their subcontractors and suppliers? These and a variety of other problems immediately suggest themselves, as the executives of the $A B C$ Corp. adjust themselves to the necessity of working out with the $X$ Ordnance District a settlement on account of the termination of their contract.

Hypothetical? Only in the details. Unusual? By no means. Already more than $x_{4,000}$ War Department contracts have been terminated for the convenience of the Government. Of these more than ro,200 have already been settled, at a total cost of more than $\$ 51,000,000$. As of August 3r, r943 there were in excess of IIo,000 War Department contracts outstanding, with a total contract price of over $\$ 75,000,000,000$, of which approximately $\$ 52,000,000,000$ represented undelivered items: The changing nature of the strategical and tactical aspects of the war, the development of new weapons, the reallocation of scarce raw materials and the development of substitute materials all emphasize the fact that many of these contracts will be terminated, in whole or in part, long before cessation of hostilities. The formulation of principles and procedures applicable to the termination of contracts for the Government's convenience is therefore a very real and immediate problem. The issuance by the War Department, in August 1943, of Procurement Regulation No. 15,8 entitled "Termination of Contracts for the Convenience of the Government," and of Technical Manual I4-320, entitled "War Department Termina.

${ }^{5} \mathrm{PR}$ 15-912. This notice is discussed in detail infra 468 .

o PR 15-936.

' War Department Technical Manual 14-320, dated July 7, 1943 (hereafter cited as TAM), C.C.H. War Law Serv. \$650r.

${ }^{8} \mathrm{PR} 15$, as well as all other PR, and TAM apply to all technical services of the War Department and to the Army Air Forces. These technical services include the Ordnance Department, Signal Corps, Corps of Engineers, Quartermaster Corps, Medical Department, Transportation Corps and Chemical Warfare Service. OPI are supplementary instructions issued by the Chicf of Ordnance which apply only to the Ordnance Department. Some of the other services have similar supplementary instructions. 
tion Accounting Manual for Fixed Price Supply Contracts" constitute that agency's recognition and solution of this problem. It is the purpose of this article to examine that solution, ${ }^{8}$ by means of a critical analysis and discussion.

While that analysis and discussion will be restricted to War Department policies and procedures this is largely due to the fact that the War Department is the only war procurement agency which has thus far made any detailed formulation of termination policies and procedures. Nevertheless, it is believed that a review of these War Department termination regulations will indicate the essential elements of any desirable termination article and the standards under which it should be administered. In addition, it is believed that such an examination of the War Department's termination policies and procedures is especially timely in view of the recent widespread attention which has been given to the whole war contract termination problem in the press and before Congress, ${ }^{10}$ and will provide some basis for the evaluation of the numerous proposals which have been made in various quarters concerning the question of termination. It is also hoped that such an examination will shed some light on the background and purpose of, and will aid in evaluating, the work of the Joint Contract Termination Board recently estab. lished in the Office of War Mobilization under the general supervision of Mr. Bernard Baruch. The members of this Board include the Under Secretary of War, the Under Secretary of the Navy, and representatives of the Treasury Department, the Maritime Commission, the Reconstruction Finance Corporation and the Foreign Economic Administration. Mr. John Hancock, Mr. Baruch's associate in this work, is Chairman of the Board. Among the first problems taken up by the Board have been the formulation of a uniform lump sum supply contract termination article to be used by all war procurement agencies and a uniform set of principles for the determination of costs in the event of termination. On January 8, I944 the Office of War Mobilization promulgated both of these and made them mandatory for use "to the fullest extent practicable in all new war contracts."11 The substantial similarity between the Office of War Mobilization's termination article and principles of cost determination and the War Department's termination article and principles of cost determination, upon which the War Department's termination policies and procedures are based, gives added emphasis to the importance of a study of those policies and procedures. Other problems being considered by the Board are a uniform clause for all subcontracts and regulations applying to its use; a determination of a policy providing for prompt partial payments and loans to contractors and subcontractors during the settlement period and the recom-

This article will restrict itself primarily to a discussion of the policies and procedures set forth

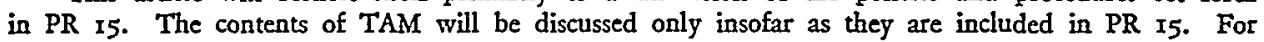
a detailed presentation of the accounting problems involved in contract terminations see Peacock, Accounting Problems in Termination, in Part II of this symposium, shortly to be published.

${ }^{10}$ For an analysis of the testimony before the Military Affairs Committees of the Senate and of the House of Representatives see infra $500 \mathrm{ff}$.

11 The text of the article (hereafter referred to as "the new standard form") is set forth in Appendix A, infra 508. The text of the Statement of Principles of Cost Determination (hereafter sometimes referred to as "the Principles") is set forth in Appendix B, infra $5 \mathrm{Ir}$. 
mendation of necessary legislation; a determination of policy with respect to the disposition of property upon termination; and a determination of policy as to the procedures, if any, to be followed by the war procurement agencies in reviewing settlements negotiated by contracting officers.

This examination will be made in the light of the ends which should be served by any termination provision and the policies and procedures thereunder, which ends may be summarized as follows:

I. Certainty to both parties should be provided, in the sense that they should know in advance what their rights and duties will be in the event of termination of the contract. Obviously this is the purpose of, and is a sufficient reason for the use of, any termination article and procedures.

2. Provision should be made for payment of the amount due the contractor for items completed, but not paid for prior to termination.

3. An expeditious and equitable method should be provided for the final determination of the amount to be paid to the contractor for the work done by him in connection with the portion of the contract which has been terminated.

4. A practicable method for the expeditious disposition of work in process and materials which the contractor has on hand at the time of termination should be provided.

5. There should be a basis for a speedy, equitable and final settlement of amounts due to subcontractors and suppliers by reason of the termination.

6. An expeditious method should be provided for making partial payments to the contractor and his subcontractors and suppliers on account of amounts due them by reason of the termination, so that their working capital positions will not be impaired pending final determination of the total amount due them by reason of the termination.

\section{Lump Sum Supply Contracts}

\section{Development and Digest of Contractual Termination Provisions}

In a defense program such as the one undertaken by the United States in the summer of 1940 it was natural that little, if any, attention would be paid to the desirability or necessity for providing in contracts for the problems which would arise should the Government at any time desire to terminate any such contract. The emphasis, quite properly, was on procurement and production, rather than on termination. A termination article was available for use, but few contracts contained it.

It was not until the summer of 194I, when the War Department undertook a complete revision of the form of lump sum supply contract theretofore in use by its contracting officers ${ }^{14}$ in the light of the procurement experience acquired by it up to that time, that any real consideration was given to the problem of termination. At that time it was determined that every lump sum supply contract thereafter entered into by the War Department would contain an article providing for termination of the contract for the convenience of the Government. A study was made of the article then provided and it was found to be unsatisfactory for a number of reasons. It made no provision for the discontinuance of work, the cancellation of orders, the termination of subcontracts, nor for the contractor's securing

14 War Department Supply Contract Form No. I, supra note 3 was the result of this revision. 
to the Government any benefits or rights under subcontracts referable to the prime contract. The only duty imposed on the contractor was to deliver to the Government the supplies, partially completed supplies, work in process and other articles which the contractor had on hand for the performance of the contract. Therefore, a new termination article was prepared and incorporated as a mandatory provision in War Department Supply Contract Form No. I which, by direction of the Under Secretary of War, was required to be used for all ${ }^{18}$ lump sum supply contracts entered into by the War Department after September 16, I941. This contract provision has since been modified from time to time, the principal modifications occurring in October 1942 , when a new paragraph was added, providing for the so-called "negotiated settlement."19 This article ${ }^{20}$ is the basis upon which the policies and procedures contained in PR $I_{5}$ and TAM are founded. Until the adoption of the new standard form it was required to be inserted in every lump sum supply contract "except contracts to be completed in six months or less for an amount less than $\$ 500,000$, and contracts for an amount less than $\$ 50,000$ regardless of the date of completion." 21 Since February 20, I944 the new standard form has been required to be inserted under the same conditions. ${ }^{22}$

Paragraph (a) of the old article contains the Government's authority to terminate the contract "at any time" by a notice in writing to the contractor. Upon receipt of that notice ${ }^{23}$ the contractor, unless otherwise directed by the contracting officer, is required to discontinue all work and the placing of all orders in connection with the performance of the contract, and to cancel all existing orders and subcontracts. He must also deliver all completed and partially completed supplies, work in process and materials as directed by the contracting officer, except that with the latter's approval or on his direction the contractor must make reasonable efforts ${ }^{24}$ to sell or retain any or all of such items at a mutually agreeable price. ${ }^{25}$

Under paragraph (b) the contractor is paid the contract price for all completed items not previously paid for. $\mathrm{He}$ is also allowed the contract price for any of such items disposed of by him pursuant to the contracting officer's direction. With

\footnotetext{
18 This requirement was subsequently modified so as not to apply to contracts to be completed in six months or less for less than $\$ 500,000$ and to contracts for less than $\$ 50,000$ regardless of the date of completion.

${ }^{10}$ Other modifications included $(x)$ permission for the sale or retention of contractor-owned property which the Government might require to be transferred to it; (2) a negotiated settlement of the amount due for post-termination expenses; (3) a provision for partial payments on account of amounts due under the article; and (4) a provision requiring termination under the terms of the article at the end of hostilities, unless the contractor was in wilful default.

20 Supra note 4.

${ }^{21} \mathrm{PR}$ 324. As a practical matter this includes virtually every War Department contract except some development contracts and spot purchases of standard stock items.

${ }^{22} I d$.

${ }^{23}$ Supra note 5.

26 While paragraph (a) of the article appears to require the contractor to sell at the contracting officer's discretion, this provision has been administratively determined to require only reasonable efforts to sell.

${ }^{25}$ See infra $47 \mathrm{I}$. For separate treatment of the property problems on termination see Mack, Disposition of Federally Owned Surpluses, in Part II of this symposium, shortly to be published.
} 
respect to the uncompleted portion of the contract, ${ }^{26}$ paragraph (c) provides for the negotiation between the contractor and the contracting officer of reasonable compensation therefor, including an allowance for profit. ${ }^{27}$ If such negotiation fails paragraph (d) sets out a formula by which the contractor's cost and profit allowance with respect to the uncompleted portion of the contract is to be computed.28

Under paragraph (e), on the basis of an agreement between the contractor and the contracting officer as to the amount thereof, the contractor is paid for the expenses incurred by him after the date of termination and with the approval of the contracting officer for the protection of Government property and in connection with the settlement of the contract. If no agreement is reached the contractor is reimbursed for his costs with respect to such post-termination expenses.

Paragraph ( $f$ ) states that the Government may assert offsets on account of any unpaid labor or material claims or any defects in material or workmanship in completed or partially completed supplies delivered by the contractor. Paragraph (g) limits the total payments under the article to an amount which, when added to the amounts previously paid under the contract, does not exceed the total contract price. $^{29}$ Paragraph (h) provides a minimum payment of $\$$ Ioo under the article. ${ }^{30}$ Partial payments to the prime contractor, for himself and his subcontractors and suppliers; are authorized under paragraph (i) ${ }^{31}$ By the terms of paragraph (j) all disputes arising out of the termination are to be disposed of in accordance with the standard disputes article. ${ }^{32}$ Paragraph (k) sets out the releases and the continued obligations and rights of the parties. Under paragraph (l) the Government's right to terminate, except for default, is restricted to its right under the article. If the contract is terminated as part of a general termination of war contracts at the cessation of hostilities, even if the contractor is then in default, the contract may be terminated only under this article, unless the default was wilful and caused substantial damage to the Government.

In addition to this old standard form there has been in effect since January 8 , 1944, the new standard form ${ }^{33}$ which is required to be inserted in new lump sum

${ }^{28} \mathrm{PR}$ 15-150.ro defines this as "that portion ... which does not relate either (a) to completed supplies called for by the contract or (b) to any . . . portion of the contract" which, by the terms of the notice of termination, the contractor must continue to perform.

${ }^{37}$ See infra 459 ff. and 480 ff. for a detailed treatment of the negotiated settlement.

${ }^{28}$ See infra 490 ff. for a detailed treatment of the formula settlement.

20 This is clearly a reasonable limitation; it would be extremely difficult to justify paying more under a contract which has been terminated prior to completion than under a contract which has been completed. Sec Delafield, Notes on Jurisdiction of the Secretary of War to Setrte Contracts, Etc. (Washington: Government Printing Office, 1920) 7 for a discussion of the similar World War I position on this problem.

${ }^{30}$ This provision appears to have been included out of an excess of caution to avoid any attack of the standard form on the ground of lack of mutuality of consideration or obligation. See infra. Actually, contractors are waiving their rights under this provision and agrecing to accept only the amount actually due them, and in many cases are settling without cost. It has been omitted from the new standard form.

${ }^{32}$ See infra $477 \mathrm{ff}$. See Cleveland, Financing of Terminations, in Part II of this symposium, shortly to be published, for a detailed treatment of the termination financing problem.

${ }^{32}$ PR 326.

${ }^{33}$ Appendix A, infra 508. 
supply contracts entered into by all the war procurement agencies, pursuant to a Directive Order of the Office of War Mobilization, ${ }^{34}$ and which may be substituted for the old form in existing contracts. The promulgation of this provision marked a successful conclusion for the efforts of the various war procurement agencies and the War Production Board which, for well over a year, had sought to agree upon a uniform termination provision. This agreement was finally achieved by the Joint Contract Termination Board in December, 1943 and was followed by the issuance of the above Directive Order, based on recommendations made to $\mathrm{Mr}$. Byrnes, Director of War Mobilization, by Mr. Baruch and Mr. Hancock. In the course of their recommendations they said:

"Manufacturers will benefit from having this Termination Article in their contracts. It will assure uniform handling of their claims by all the agencies with which they have contracts, eliminating possible conflict and confusion over varying contract provisions; it will make for swifter and more equitable settlement, give manufacturers a clear definition of their rights; reduce litigation.

"The desirability of having a standard Termination Article for all agencies has been generally recognized. It has been advocated by business groups; independent organizations; the procurement agencies themselves as well as several important committees of Congress including those headed by Senators George and Murray."

This new standard form contains few substantial deviations from or additions to the old standard form or the principles in accordance with which it is administered. Paragraph (a), as in the case of the old form, authorizes partial or complete termination at any time in the interest of the Government, upon service of a notice of termination. If the contract is terminated as part of a general termination of contracts made by the particular agency for the same or related products, or of war contracts generally at the cessation of hostilities or a major portion thereof, termination may be only in accordance with the article unless the contractor is then in gross or wilful default. These limitations are an improvement over paragraph (1) of the old standard form, which was restricted to a general termination of all war contracts at the cessation of hostilities, and also required a finding that the contractor's default resulted in substantial damage to the Government, if the default provisions of the contract were to be invoked at that time. The new form is broader, and properly provides for the contingency of a discontinuance of production of a particular product or related group of products, as well as for the very real possibility of the end of the European phase of hostilities before the Asiatic phase. It seems clear that in both these situations a contractor who has not wilfully defaulted should be assured of the protection afforded under a terminationfor-convenience article.

Paragraph (b) of the new standard form places on the contractor who has received a notice of termination all of the duties set forth in paragraph (a) of the old form, plus a duty to settle claims arising out of the termination of subcontracts, with the approval or ratification of the contracting officer to the extent that he may

a4 9 Fed. Reg. 478 (January I2, 1944). 
require, ${ }^{35}$ and a duty to use his best efforts ${ }^{36}$ to sell property on hand as a result of the termination. In making such sales the contractor cannot be required to extend credit to any purchaser. ${ }^{37}$

Paragraph (c) authorizes the negotiation of the settlement on termination. It contains an innovation in that the settlement may be negotiated with respect to the whole or any part of the amounts due by reason of the termination, thereby making possible a hybrid negotiated settlement and formula settlement, and apparently includes authority to negotiate a price other than the contract price for completed articles delivered after the effective date of the termination notice, ${ }^{88}$ since such articles would be included in the terminated work, not having been delivered prior to termination. The negotiations, apparently, are intended to include payment to the contractor for expenses incurred by him for the protection of Government property and in connection with the settlement, since the new article has no provision similar to paragraph (e) of the old article, which expressly authorizes the negotiation of these amounts. Also, under the new article the amount agreed upon in the negotiation is not limited to the total contract price less amounts pre. viously paid under the contract, as provided in paragraph $(\mathrm{g})$ of the old article. While this provision affords the Government little real protection its omission and the omission of other restrictions on the negotiations indicate an apparently definite and deliberate effort to make a contracting officer as free in negotiating a settlement as he is in negotiating a contract price originally. Paragraph (c) also expressly states that the amount agreed upon under its terms is in no way limited or affected by the provisions of paragraph (d), setting forth the formula basis of settlement. While this confirms the contracting officers' wide latitude of discretion in negotiating settlements, it may be questioned how far as a practical matter they will be willing to depart from an approximation of the formula result as a guide in their negotiations, ${ }^{39}$ since payment of an amount which approximates what would have been paid under the formula is readily justifiable, while payment of an amount out of line with any estimate of the formula result could be expected to be subjected to considerable scrutiny.

Perhaps the most important change is that contained in the terms of the formula to be applied in the event negotiations fail. This formula provides for payment of the contract price for articles which have been completed, delivered and accepted but which have not previously been paid for. ${ }^{40}$ With respect to all terminated

${ }^{35} \mathrm{Cf}$. infra $474 \mathrm{ff}$. $\quad{ }^{36} \mathrm{Cf}$. supra note 24 .

${ }^{37}$ To the same effect see PR 15.364.

${ }^{38}$ The new standard form contains no counterpart to paragraph (b) of the old standard form, which provided for payment of the contract price for completed articles delivered after the termination notice takes effect.

${ }^{30}$ See infra $48 \mathrm{x}$.

${ }^{10}$ Completed acceptable arcicles which have not been delivered apparently are to be included under paragraph (d) (2), dealing with payment for terminated work, the theory being that delivery is part of the work which has been terminated. However, since the majority of contracts are f.o.b. contractor's plant it would appear that contracting officers would be well advised to avail themselves of the authority they have under paragraph (b)(6)(i) to require transfer of title and delivery to the Government of completed acceptable work, and pay the contract price therefor, thereby eliminating such items from the eategory of work in process under paragraph (d)(2) and simplifying the computation under that paragraph. 
work the contractor is to receive his costs, plus the cost of work delivered by his subcontractors prior to termination, and the amounts paid to his subcontractors in settlement of their claims with respect to their terminated work. ${ }^{41}$ Pursuant to paragraph (b) (5) the contracting officer may require that some or all of such settlements be submitted to him for approval.

In addition to these costs the contractor is paid a profit on terminated work, based on rates previously negotiated. At the time the contract is negotiated, or at the time the contract is amended to include the new standard form, the parties negotiate a rate not to exceed $2 \%$ on the cost of articles or materials on which the contractor will have done no work at termination, and a rate "which is fair and reasonable under the circumstances" on all other costs incurred by the contractor, excluding settlements with subcontractors. ${ }^{42}$ The total profit, however, is limited to $6 \%$ of the total of these two types of costs, exclusive of interest on loans made by the contractor in furtherance of the work. This method of profit determination is in marked contrast to the method under paragraph (d) under the old standard form which, far from being a true formula, is based on the contracting officer's estimate of the profit which the contractor would have earned had he completed the contract. Undoubtedly a contractor's estimate as to the result which would be reached under either of these two provisions will have much to do with his decision as to whether to insert the new form in a particular existing contract.

Under the formula the contractor also is paid the reasonable cost of preserving and protecting Government property after termination and the expenses incidental to determining the amount due him as a result of the termination. Undoubtedly this would include his accounting, legal, clerical and other expenses in connection with his settlements of his subcontracts and the preparation and presentation of his settlement proposal and supporting data. ${ }^{43}$ Expenses of litigation with subcontractors would probably not be included unless such litigation had been approved or ratified by the contracting officer since his would be the ultimate decision as to whether a subcontractor was entitled to the amount claimed by him, inasmuch as ultimately the Government would be paying it. Expenses of litigation by the contractor against the Government would probably not be included in any event; clearly these cannot arise either in connection with a negotiated or a formula settlement, but only after the amount due has been computed under the formula and the contractor has refused to accept that amount. Furthermore, paragraph I (k) of the Principles of Cost Determination, which by paragraph (h) of the new standard form is incorporated by reference for the purposes of the formula, ex-

\footnotetext{
¿1 The preceding note would appear to apply equally well as between a prime contractor and a subcontractor who has on hand at termination some completed and acceptable, but undelivered, work.

${ }^{42} \mathrm{PR} 324$ recommends the general use of $2 \%$ and $8 \%$ as arbitrary figures "in the interest of expediting the execution of contracts." However, where it is not desired to use these arbitrary figures for any reason the percentages are to be arrived at by the same methods "as those now used in price analysis," i.e., original negotiations.

${ }^{4}$ See Statement of Principles, Appendix B, infra $51 \mathrm{l}$, par. $\mathrm{I}(\mathrm{k})$.
} 
pressly limits the contractor's settlement expenses to those necessary for the prepara. tion and presentation of his settlement proposal and supporting cost evidence.

The formula provision also contains a limitation as to the total amount which may be paid. (As indicated above the new article contains no limitation on the total amount which may be paid in the case of a negotiated settlement.) This limitation is the same as the one set forth in paragraph (g) of the old standard form as applicable to either a negotiated or a formula settlement, i.e., the total contract price less payments previously made and less the contract price for work not terminated, except that post-termination expenses are not to be included in applying the limitation in the new article, whereas they are included under the old article. Paragraph (d) also places on the contractor the risk of loss, destruction, damage or theft of property prior to transfer of title thereto to the Government or a buyer, or prior to the sixtieth day after delivery to the Government of an inventory covering such property, whichever occurs sooner. A similar limitation appears in the formula provision of the old standard form except as to the sixty day limit of contractor liability. This innovation is in keeping with the present indications that the Joint Board intends to authorize contractors to require the Government to remove property which has not been disposed of within sixty days after presentation of an inventory listing such property. ${ }^{44}$

Paragraph (e) of the new standard form is similar to paragraph ( $f$ ) of the old form. It provides for deductions from the negotiated or formula amount to be paid the contractor on account of unliquidated advance or partial payments, claims of the Government against the contractor and disposal or retention credits for property. It also furnishes a measure of protection to subcontractors in that it authorizes the contracting officer, in his discretion, to withhold the amount of the claim of any subcontractor whose subcontract has been terminated, except with respect to that portion of the claim representing articles delivered to the prime contractor or services performed in connection with the production of completed articles under the prime contract. This represents an improvement over the old paragraph $(f)$ which authorizes deductions on account of "any unsettled claim for labor or material." Since the contracting officer does not ordinarily have any information as to whether claims of subcontractors have actually been paid, presumably a subcontractor desiring to be protected by a deduction in his behalf would have to notify the contracting officer that his claim had not been paid. It is not believed that the provision requires the contracting officer to take any affirmative action to determine whether any claims of subcontractors are unpaid at the time he makes payment to the prime contractor.

Paragraph $(f)$ of the new article makes express a right which has always been thought to exist, that of making an "appropriate, fair and reasonable adjustment" in the contract price of articles to be delivered under the part of a contract which is not terminated. Paragraph (g), like the old paragraph (i), authorizes partial:

"See infra note 119. 
payments whenever the contracting officer believes the total of such payments is within the amount the contractor will ultimately receive. Paragraph (h) incorporates by reference, but only for the formula settlement, the Principles of Cost Determination which were promulgated together with the new article.45 However, these same principles will be applied by contracting officers as guides in arriving at negotiated settlements, since these principles are now incorporated in PR I5 as such guides. ${ }^{45^{2}}$ Except under unusual circumstances it would appear to be extremely difficult to justify any other course of action, since the negotiations will undoubtedly be carried on with an eye to the result which would be reached if the formula were to be applied.

While the new standard form will appear in virtually all new contracts entered into since its adoption the old standard form will continue to play a significant part in terminations, if only for the reason that it now appears in thousands of contracts and many contractors may be expected not to avail themselves of the right to substitute the new form, for a variety of reasons, not the least of which will be sheer inertia. ${ }^{16}$

\section{The Negotiated Settlement}

The greatest innovation in both the old and the new standard forms, and the respect in which they differ most from all of their predecessors, is the inclusion in them of a provision for a final settlement by negotiation between the contractor and the contracting officer ${ }^{47}$ of the amount, including profit, which the contractor is to receive because of the termination. ${ }^{48}$

The inclusion of this provision for a final negotiated settlement represents the utilization of long-existing authority both in private and Government contract law, in order to achieve the ends of equitable, speedy and final disposition of termination settlements. The method of negotiation and agreement is the normal method adopted by businessmen in compromising their obligations. It is based on the common law rule that the parties to a contract may negotiate between themselves and agree on the amount to be paid in settlement of their unliquidated obligations.

\footnotetext{
${ }^{15}$ See infra 483 ff.

45a PR 15-480 ff.

${ }^{10} \mathrm{PR} 324(4)$ states that inasmuch as it is in the mutual interest of the contractor and the Government that terminations be effected under a uniform article, contracting officers should pursue "a vigorous policy" to insert the new article in existing contracts, especially those for large amounts and those calling for deliveries over a long period of time.

"7 Actually, of course, the contracting officer functions through a large organization rather than as an individual.

${ }^{8}$ The new form provides that the "contractor and the contracting officer may agree upon the whole or any part of the amount or amounts to be paid to the contractor by reason of the total or partial termination of work pursuant to this article, which amount or amounts may include a reasonable allowance for profit, and the Government shall pay the agreed amount or amounts."

The old form provides that "the Government shall pay to the contractor such sum as the contracting officer and the contractor may agree by supplemental agreement is reasonably necessary to compensate the contractor for his costs, expenditures, liabilities, commitments and work in respect to the uncompleted portion of the contract so far as terminated by the [termination] notice.... The contracting officer shall include in such sum such allowance for anticipated profit with respect to such uncompleted portion of the contract as is reasonable under all the circumstances."
} 
In ordinary commercial transactions the courts favor such settlements, under which all the unliquidated obligations of the parties are merged in the final agreement, which is legally enforceable as a so-called accord and satisfaction. ${ }^{40}$

With respeçt to Government contracts, the final determination by negotiation between a Government contracting officer and a contractor of the amount due the contractor because of the termination of his contract has had the express approval of the Supreme Court of the United States since 1876 . In that year the Court, in the case of United States v. Corliss Steam-Engine Co., ${ }^{50}$ ruled that the Secretary of the Navy could properly agree with a Navy contractor as to the amount to be paid that contractor in settlement of the Government's obligation with respect to the uncompleted portion of a contract terminated in the interest of the Government and that, in the absence of "fraud, concealment or misrepresentation" in the negotiation of that agreement, the contractor was entitled to recover the amount agreed upon. As an indication of the necessity of such conclusion the Court said:

"If such a settlement, . . . accompanied by the giving up by one, and the taking possession by the other of the property involved, cannot be judicially maintained, it would seem that no settlement by any contractor with the Government could be considered a finality against the Government."51

The Court supported its decision on two other grounds, both of which are so completely a propos the difficulties confronting the war procurement agencies today that it might be well to set them out in detail:

"The duty of the Secretary of the Navy ... extends ... to 'the procurement of naval stores and materials and the construction, armament, equipment and employment of vessels of war, as well as all other matters connected with the naval establishment of the United States.' . . . [The] discharge of the duty devolving upon the Secretary necessarily requires him to enter into numerous contracts for the public service; and the power to suspend work contracted for, whether in the construction, armament or equipment of vessels of war, when from any cause the public interest requires such suspension, must necessarily rest with him. As, in making the original contracts, he must agree upon the compensation to be made for their entire performance, it would seem that when those contracts are suspended by him, he must be equally authorized to agree upon the compensation for their partial performance. Contracts for the armament and equipment of vessels of war may, and generally do, require numerous modifications in the progress of the work, where that work requires years for its completion. With the improvements constantly made in shipbuilding and steam machinery and in arms, some parts originally contracted for may have to be abandoned, and other parts substituted; and it would be of serious detriment to the public service if the power of the head of the Navy Department did not extend to providing for all such possible contingencies by modification or suspension of the contracts, and settlement with the contractors. . . .

"But aside from this general authority of the Secretary of the Navy, under the orders of the President, he was, during the [war], specially authorized and required by Acts

${ }^{10}$ In re Illinois Refrigerator Co. 73 F. (2d) 88I (1934); Jaffray v. Davis 124 N. Y. I64, 26 N. E. 35 I (r89i). See 6 Williston, Contracts (2d ed. 1936) 5204, n. 4 .

${ }^{50} 9 \mathrm{x}$ U. S. $32 \mathrm{x}(1876)$. See also Pittsburgh Plate Glass Co. v. United States $64 \mathrm{Ct} . \mathrm{Cl} .256$ (r927); 14 Comp. Dec. 589 (1908); 18 CoMp. Gen. 826 (1939); 22 Op. ATtr. Gen. 437 (1899).

${ }^{52}$ United States v. Corliss Steam-Engine Co., stupra note 50, at 322. * 
of Congress, either in direct terms or by specific appropriations for that purpose, to construct, arm, equip and employ such vessels of war as might be needed for the efficient prosecution of the war. In the discharge of this duty, he made the original contracts with the claimant. The completion of the machinery contracted for having become unnecessary, from the termination of the war, the Secretary, in the exercise of his judgment, under the advice of a Board of naval officers, suspended the work. Under these circumstances, we are of opinion that he was authorized to agree with the claimant upon the compensation for the partial performance, and that the settlement thus made is binding upon the Government." 52

The Budget and Accounting Act of $1921,{ }^{53}$ which established the position of the Comptroller General and the General Accounting Office and which is the basis for that officer's authority to review Government contracts, has had no effect on the exercise by an administrative department of the power to negotiate settlements in connection with the termination of contracts placed by such department. Any authority which the Comptroller General might assert to pass upon such settlements would be based on the provision of the Act which states that:

"All claims and demands whatever by the Government of the United States or against it ... shall be settled and adjusted in the General Accounting Office."

However, in speaking of this provision the Supreme Court in the case of Globe Indemnity Co. v.' United States ${ }^{54}$ said:

"But none of these duties imposed on the Comptroller General were new. . . . The chief change effected by the Budget and Accounting Act was that it transferred powers lodged with officers of the Treasury Department to the Comptroller General and made his office independent of the executive branch of the Government. But the function which he exercises in auditing and settling claims against the Government is precisely that which was previously exercised by the Accounting Office in the Treasury Department."

Consequently the Corliss case may still be regarded as a statement of the law presently applicable to the negotiation of termination settlements on Government contracts.

In addition to the Corliss case, additional support for the use of the negotiated settlement was provided by an opinion of the Attorney General ${ }^{56}$ to the effect that the First War Powers Act $^{57}$ and Executive Order No. $9001^{58}$ authorized the War Department to settle claims and obligations against the United States without reference to the General Accounting Office where to do so would facilitate the prosecution of the war..$^{59}$ The question was thereafter submitted to the Judge

5s Id. at 322, 323 (ital. added).

Es 42 STAT. 20 (I92I) 3 I U. S. C. I940 ed. §ईI ff.

st 291 U. S. 476 (1934).

${ }^{55} I d$. at 480 .

to 40 OP. ATtY. Gen. No. 53 (1942).

вт 55 Stat. 838; 50 U. S. C. App. \$60r (Supp. r94I).

68 Fed. Reg. 6787 , C.C.H. War Law Serv. I2401, PrentTce-Hal., Nat. Def. Serv. q13026.

${ }^{50}$ See Hearings before a Subcommittee of the Senate Committee on Military Affairs on S. 1268, S. 1280 and $S$. J. Res. 8o, 78 th Cong., Ist Sess. (1943) (hereafter cited as Senate Hearings) 343, 352, for testimony by Attorney General Biddle to the effect that contracting officers have always had this power and the First War Powers Act, supra note 57 , in no way affected this power. 
Advocate General of the Army on the theory that the negotiated settlement procedure would facilitate the prosecution of the war in that it would provide a method for expeditiously settling terminated contracts by avoiding the great volume of accounting and auditing which would otherwise be necessary to support vouchers drawn pursuant to any termination under the formula. In an opinion dated September $16,1942,{ }^{60}$ the Judge Advocate General found that where it has been administratively determined that such action will facilitate the prosecution of the war, contracts may be terminated for the convenience of the Government by entering into supplemental agreements authorizing negotiated lump sum settlements whether or not the contract being terminated contains any other method of termination and settlement. Termination articles in use up to that time had made no attempt to set forth a basis for the negotiation of a settlement. Thus the previous termination clause provided for the settlement of the obligations with respect to the uncompleted portion of the contract by a formula which was based upon a determination of the actual costs of the contractor with respect to such uncompleted portion. This would have necessitated a detailed audit in every case to determine such costs and the preparation of adequate accounting data and original supporting papers to satisfy the requirements of the General Accounting Office with respect to any such determination, irrespective of the fact that the department settling the contract had made a careful accounting review as a preliminary to the negotiation of the settlement. The Comptroller General and the Comptroller of the Treasury, whose office preceded the General Accounting Office, also ruled that if a contract sets forth a method of settlement on termination this method would have to be followed unless it could be demonstrated that any other method sought to be applied would operate in the Government's interest. ${ }^{63}$ Thus, as a practical matter, every contract providing for a termination settlement under the formula would require compliance with the formula provision, if only to demonstrate that the negotiated settlement proposed as a substitute was in the Government's interest.

The full significance of this situation was not appreciated until the summer of 1942, when the Ordnance Department found itself faced with the War Department's first large termination, involving a contract of approximately $\$ 7,000,000$. A preliminary survey revealed that this one case would necessitate the full time services of fifteen auditors for a period of approximately nine months in order to make a virtually $100 \%$ audit, the type of determination of the costs with respect to the uncompleted portion of the contract which was then thought necessary to satisfy the audit requirements which would be applied to a formula settlement. Obviously this was both undesirable and impracticable, since it did not meet the end of an expeditious and final determination of the amount due, both for this one case and certainly if this requirement were to become a general practice. 01

${ }^{\circ 0}$ SPJGC 164 , September 16,1942 ,

${ }^{03}$ MS B-28750, Oct. I, I942; 25 COMP. DEc. 398 (1918). See Ohio Savings Bank \& Trust Co. v. Willys Corp. 16 F. (2d) 859, 862 (1926).

o" In another case, involving approximately 3,300 claims through the third tier of subcontractors, it was estimated that 13,440 man days, the equivalent of fifty men working eleven months, would be 
It was clear, however, that under the Corliss doctrine that end could be met while at the same time the Government's interests would be fully protected. This protection would be the result of the application of businesslike selective audit procedures adequate to fit each particular case and varying in scope and detail as the cases would vary in complexity. Since the War Department in any event would be passing on every termination in the first instance it was believed un. necessary for the General Accounting Office to duplicate this audit, especially since the law did not appear to require it. On the other hand, every settlement would be open to scrutiny by the General Accounting Office at any time and the payments thereunder subject to disallowance by that agency in the event it discovered fraud or other illegality. Therefore, in reliance on the Corliss case and the aforementioned opinions of the Attorney General and of the Judge Advocate General of the Army the provision for the negotiated settlement was incorporated in the standard termination article.

While this step was being taken the Comptroller General, on October I, I942, issued a decision ${ }^{65}$ which focused new attention on the whole problem of termination settlements. In that decision he took the position that a termination under the formula necessitated a satisfactory demonstration that the costs being allowed had actually been incurred by the contractor. The contract involved in this case contained the termination article which had been adopted in September I94I and which contained no provision for the negotiation of settlement. Upon the termination of the contract, a supplemental agreement had been entered into, setting forth the amounts to be paid to the contractor for his material and overhead costs with respect to the uncompleted portion of the contract, for the amounts paid by him in discharge of the outstanding obligations he had incurred with respect to the uncompleted portion of the contract and for his profit on the uncompleted portion of the contract. The contracting officer supported his determination of these amounts by statements showing how they had been computed and showing the names of the suppliers to whom cancellation charges had been paid by the contractor. In addition the contracting officer certified that an audit had been made of the contractor's expenditures, that fair salvage values had been credited and that the profit allowance was based on the percentage of completion of the uncompleted portion of the contract. While the Comptroller General conceded that he had previously ruled ${ }^{67}$ that a contracting officer may terminate a contract and agree with the contractor upon the compensation to be paid to the contractor for work already performed, he held that this did not apply where the contract already contained a provision for termination on another basis. Where, as in this case, such a provision existed in the contract he ruled that the issues were whether the termination provision authorizes payment of the items proposed to be paid, whether

required to complete a full, detailed audit of every item involved, as against five men working four months to complete an office review and an adequate selective audit to provide the accounting data necessary for the negotiation of a settlement.

${ }^{\text {OS }}$ MS B-28750, Oct. I, I942.

${ }^{67}$ I8 COMP. Gen. 826 (1939). 
the amounts have been determined in accordance with the provisions of the contract and whether they are supported by such evidence as may be' required by the contract or as may otherwise be required for the protection of the interests of the United States. He took the position that these requirements had not been met in this case, since there was no evidence before him of the contractor's actual expenditures, ${ }^{68}$ in the form of receipts, cancelled checks, or similar original evidence, or at least in the form of an audit by a Government representative based on adequate evidence. Therefore he, ruled that payment of the amounts agreed upon in the supplemental agreement would be unauthorized and returned the case for compliance with his requirements as to evidence. Undoubtedly this complete lack of supporting data was the basic reason for this ruling. On the other hand, there is no indication in the decision that the Comptroller General would insist on a strict dollar-for-dollar audit. There is some likelihood, in fact, that he would have regarded the application of reasonable selective audit procedures as sufficient, especially since he permits the utilization of such procedures in connection with the audit of cost-plus-a-fixed-fee contracts. ${ }^{69}$. In any event, however, he would un. doubtedly have insisted on reviewing the audits and other evidence relied on by the contracting officer in making his determination. ${ }^{70}$ Nevertheless, whatever may have been the intention of the Comptroller General in rendering this decision, its practical effect has been that more than a year later the case had not yet been com. pleted. Also, either because of this decision or purely coincidentally, virtually every termination settlement arrived at has been made on a negotiated basis. ${ }^{71}$

There is little doubt that, given the opportunity, this great preponderance in favor of the negotiated settlement will continue ${ }^{72}$ and will make possible a speedy, equitable and final determination of the amount due the contractor on each termination, at the same time adequately protecting the interests of the Government. ${ }^{73}$ That such a result is highly desirable is evident from a consideration of the following practical advantages of the negotiated settlement:

I. A detailed audit is extremely time-consuming; on a lump sum contract where, unlike a cost-plus-a-fixed-fee contract, the contractor had no reason to believe that detailed cost records and other documentary evidence would ever be required, it is extremely difficult to piece together the volume of data required for a precise audit.

${ }^{68}$ The termination article provided for the payment of "all actual expenditures" of the contractor.

${ }^{\circ}$ War Department Manual for the Administrative Audit of Cost-Plus-a-Fixed-Fee Supply Contracts, May 27, r942, Part III, entitled "Application of Selective Audit Procedures," indicates that in auditing cost-plus-a-fixed-fee contracts reliance is to be placed on the contractor's own system of internal controls where adequate, and directs the utilization of selective audit procedures by Government auditing personnel wherever possible.

${ }^{70}$ Senate Hearings 221.

${ }^{71}$ Hearings before the Committee on Military Affairs of the House of Representatives on $H . R .3022$, 78th Cong., Ist Sess. (1943) (hereafter cited as House Hearings) 45. Colonel R. Ammi Cutter, Chicf, Legal Branch, Office of the Director of Material testified that "practically no cases have been settled by formula, that in most instances it has been possible to reach a negotiated settlement."

${ }^{72}$ Of more than thirty witnesses representing the Government and industry in the Senate and House Hearings only the Comptroller General opposed the negotiated settlement.

${ }^{73}$ House Hearings 151, 152; Senate Hearings 300-307; infra 506. 
In many cases, particularly among subcontractors, such records are wholly nonexistent. The negotiated settlement makes possible an adequate, yet not unduly prolonged, review of contractors' and subcontractors' settlement proposals, the nature of the review being adjusted to the needs of the particular situation.

2. No termination of any complexity is ever settled in one step. A final settlement agreement is actually the sum total of numerous decisions made during the entire period of negotiation, and involving such diverse problems as, for example, the disposition of property, the approval of settlements with individual subcontractors as they are made, the making of partial payments and the evaluation of raw and semi-processed inventories. These interim decisions require the exercise of practical, on-the-scene, business judgments which can best be made by those who were responsible for the original procurement and who are familiar with the individual items and claims involved in the settlement. The negotiated settlement makes this possible.

3. In making these necessary step-by-stép decisions many problems inevitably arise which are not susceptible of exact demonstration and as to which reasonable businessmen and even skilled accountants may honestly differ. Nevertheless these honest differences are of the sort which can be and are compromised on a reasonable basis in ordinary commercial relationships. The negotiated settlement makes such reasonable compromises available in dealing with the Government.

\section{The Right to Terminate}

Under the common law the reservation by one party to a contract of the right to terminate the contract does not render it invalid for lack of mutuality of consideration or obligation where the exercise of that right of termination is accompanied. by some detriment to the party terminating. ${ }^{74}$. Some restriction on the exercise of the right of termination, as, for example, the requirement that a written notice of termination be served, is held to be a sufficient legal detriment to the party terminating to satisfy the requirement of consideration. ${ }^{75}$

Both the old and the new standard forms of termination articles readily qualify, under both of these tests, as a reservation of the right of termination which does not render the contract voidable. Paragraph (a) makes service of a written notice necessary for the exercise of the right. The provisions of paragraphs (b), (c), (d) and (e), requiring the Government, on termination, to pay the contractor for completed items, costs and a reasonable profit with respect to the uncompleted portion of the contract, and the contractor's post-termination expenses clearly

\footnotetext{
${ }^{74}$ Petroleum Refractionating Corp. v. Kendrick Oil Co. 65 F. (2d) 997 (I933); Gurfein v. Werbelovsky 97 Conn. 703, II8 Atl. 32 (I922); Harlow v. Oregonian Publishing Co. 45 Ore. 520, 78 Pac. 737 (1904). See $x$ Wiluston, Contracts (2d ed. 1936) 353; Note (1932) I7 Corn. L. Q. 479, 481; Corbin, Effects of Options on Consideration (1925) 34 YaLE L. J. 57I, 583.

${ }^{70}$ Ford Motor Co. v. Alexander Motor Co. $223 \mathrm{Ky} .16,2 \mathrm{~S}$. W. (2d) I031 (I928); Gurfein v. Werbelovsky supra, note 74; Philadelphia Storage Battery Co. v. Mutual Tire Stores 16I S. C. 487, I59 S. E. 825 (1931), See I Williston, Contracts (2d ed. 1936) 365; 4 id. 2856; Note (1932) I7 CoRn. L. Q. $479,48 \mathrm{r}$.
} 
constitute a detriment to the Government -which it assumes when it exercises its right of termination. ${ }^{76}$

However, given a valid cancellation article from the point of view of consideration, the terms of that article clearly become the subject matter for negotiation between the parties to the contract. There can be no objection, therefore, to a termination article which limits the payment by the party terminating to something less than the common law measure of damages-the loss of full anticipated profitsince that limitation is one of the terms of the contract for which the parties will be regarded as having bargained.

The War Department, in considering the question of its right to terminate, has apparently proceeded in accordance with the foregoing analysis. Thus, PR 15I04 states that the authority to terminate contracts for the convenience of the Government is reserved in contracts on the basis of the War Department's general authority to make and amend contracts by negotiation; ${ }^{77}$ in other words, the inclusion of a termination article, either originally or by amendment, is part of the consideration bargained for in the negotiation of the contract or the amendment. ${ }^{78}$ War Department contracting officers are now required to include the standard form of termination article in every lump sum supply contract except "contracts to be completed in six months or less for an amount less than $\$ 500,000$ and contracts for an amount less than $\$ 50,000$ regardless of the date of completion."70 If for any reason the standard form of termination article has not been included in a contract it may be added by supplemental agreement at any time. ${ }^{80}$ Contracting officers are urged to make such amendments at any time "in order to facilitate prompt settlement of contracts and to encourage uniformity of procedure"; 81 they are required to attempt to make such amendments in all contracts which are about to be terminated and which contain some termination article other than the standard form..$^{82}$ Indeed, such amendments may be made "even after the giving of notice of termination" 83 and "at any stage of the settlement procedure."84

${ }^{70}$ See supra note 30 .

77 This authority is contained in 54 STAT. 712 (1940), 50 U. S. C. App. \$1171 (Supp. 1942), con inued in effect by 56 STAT. 314, 50 U. S. C. App. $\$ 773$ (Supp. r942), and in 55 STAT. 838 (1941), 50 U. S. C. App. §601 (Supp. r942).

${ }^{70} \mathrm{PR}$ 324. ${ }^{80} \mathrm{PR}$ I5-107.I.

${ }^{81}$ PR 15-107. The War Department's view of the advantages to be derived from the use of the standard form is stated in PR 15-107.3 as follows:

"Its use (a) will reduce expense, expenditure of time, auditing difficulties and administrative inconvenience both for the Government and for the contractor, and (b) helps to eliminate the obstacles to procurement which arise from the apprehension, frequently expressed by contractors, that there will be long delays in the making of settlements in the event of the termination of contractual instruments for the convenience of the Government (including any such terminations which may take place as the result of the conclusion of hostilities). Use of such standard articles and provisions will also assist materially in enabling contractors affected by terminations to undertake other war work or other productive enterprise at an early date, in a manner consistent with the public interest."

${ }^{82}$ PR $15-310$ (2).

${ }^{83}$ PR 15-107.1. See SPJGC 1943/10937, Oct. 15, 1943.

84 PR $15-310$ (5). See infra 469 for a discussion of "termination" as cutting off a contractor's rightit to proceed with performance, but leaving the contract otherwise executory. 
"Contracts containing no termination article may be terminated and finally settled by supplemental agreement where such termination is to the interest of the Government."85 Even here, however, and apparently to avoid the consequences of a breach of contract, ${ }^{86}$ the contract is to be amended wherever possible to contain the standard form of termination article, or to provide some other mutually acceptable basis of settlement, ${ }^{87}$ either before or after the contractor has been ordered to stop work. ${ }^{88}$ Where no satisfactory agreement can be reached with the contractor, he may nevertheless be ordered to discontinue further performance. ${ }^{89}$ This the War Department recognizes as a breach of contract; PR I5-3II(4) states that the "contractor may thereafter present his claim, if any, for damages arising out of this order, to the General Accounting Office or other courts for settlement." However, PR I5-3II (4) discourages the use of such orders to stop performance, stating that it "is not consistent with War Department policy for the Government to commit breaches of contract and such action will be taken only in unusual cases and where all other reasonable efforts to prevent the incurring of unnecessary expense for the Government have been exhausted." Thus, the War Department's whole approach to the problem of its right to terminate contracts at any time for its convenience is entirely consistent with the general law respecting the termination or cancellation of contracts.

\section{The Choice of a Contract to Be Terminated}

Why are contracts terminated? Why is contract A terminated, rather than contract $B$ ? The ultimate answer to these questions is to be found in the rapidly changing nature of modern warfare, which necessitates frequent revisions in the supply requirements of the armed forces. The plane, tank or gun which is an effective weapon today may be totally obsolete tomorrow. The resulting modifications in requirements are normally made by the adjustment of general supply programs by the General Staff. The translation of such overall changes into total or partial terminations or revisions of specific contracts is the function of the chief of the technical service responsible for the procurement of each item involved, or of such officials as he may designate for that purpose..$^{90}$

To aid in the making of these decisions as to the contracts to be wholly or partially terminated certain factors have been set up by the Office of War Mobilization, the War Production Board and the War Manpower Commission for consideration in the placement and termination of contracts. ${ }^{91}$ Among these factors are the ability of the contractor to produce at the time and in the quantity and quality required; ${ }^{92}$ the relief of labor shortage situations; ${ }^{93}$ the efficiency of the contractor

${ }^{85}$ PR I5-3II (I). See I8 CoMp. Gen. 826 (I939).

${ }^{8 B}$ House Hearings 36.

${ }^{88} \mathrm{PR}$ I5-3II (2); (4).

${ }^{87}$ PR I5-3II (3).

${ }^{80}$ PR 15-3II (4).

${ }^{\circ} \mathrm{PR}$ 15-102; 15-301. Under PR 15-206 any authority of a chief of a technical service concerning termination may be redelegated by him, except where otherwise expressly directed. The authority to order specific terminations may be so redelegated.

${ }^{91}$ PR 223.

${ }^{03}$ PR 223.2.
${ }^{03} \mathrm{PR} 223.3 ; 223.4 ; 223.5$. 
in terms of his use of minimum manhours and materials; ${ }^{94}$ utilization of small business $;{ }^{95}$ conservation of most able contractors for the more difficult contracts; ${ }^{96}$ avoidance of the completion of new facilities; ${ }^{97}$ conservation of transportation facilities; ${ }^{98}$ and the preservation of more than one source of supply. ${ }^{90}$ The purpose, as it should be, appears to be to fit contract terminations into the overall supply picture in such a way as to aid production generally, while at the same time making necessary specific adjustments.

\section{The Notice of Termination and Preliminary Termination Procedures}

The decision to terminate a particular contract having been reached, the first step in the process of termination ordinarily ${ }^{100}$ is the transmission of that decision to the contractor by means of the service of a notice of termination. This notice is to be served in writing, by hand, by registered mail or by telegram. ${ }^{101} \mathrm{~A}$ copy of the notice is to be sent to any assignee, guarantor or surety on the contract, since their interests may be vitally affected by the termination..$^{102}$ The notice ${ }^{103}$ states the date on which the termination is to take effect, which in no event may be earlier than the date of delivery of the notice; the fact that the termination is pursuant to the termination article in the contract; the scope of the performance to be discontinued; and, in the case of a partial termination, the scope of the performance to be continued. It directs the contractor to stop all work and the placing of any further subcontracts or purchase orders; to terminate existing subcontracts and purchase orders, ${ }^{104}$ except any specific subcontracts or purchase orders which are not to be terminated; to submit, as promptly as possible, a statement of costs and a proposal for a negotiated settlement; ${ }^{105}$ an inventory; and a statement of costs and the proposal for a negotiated settlement from each subcontractor and supplier. ${ }^{106}$ It also contains any special directions for the care of Government property in the contractor's possession and any directions or limitations which can then be given with respect to the sale or retention of contractor-owned property acquired

${ }^{24} \mathrm{PR} 223.7$.

${ }^{90} I d$.

${ }^{88} I d$.

${ }^{95} I d$.

${ }^{97} \mathrm{Id}$.

${ }^{90} \mathrm{Id}$.

${ }^{200}$ In some cases the complexity of a proposed termination may make it desirable to confer with the contractor even prior to service of the notice of termination. At such a conference there would be discussed the most desirable effective date of termination; work in process to be completed; status of completion of prime and subcontracts; financial problems of the contractor; possible creation of unemployment or labor problems; and steps to be taken by the contractor on termination. Sec PR 15-312.

${ }_{101}$ PR 15-320. PR 15-9II sets forth the form of telegraphic notice. PR I5-912.I sets forth the form of the complete notice.

${ }^{102} \mathrm{PR}$ 15-320. None of these can object to the termination, since it is the exercise of a right provided for in the contract. However, quaere whether a surety or guarantor might refuse to consent to the insertion of the standard form by supplemental agreement, either before or after termination. It is difficult to see how such amendment changes the nature of the contractor's obligation; furthermore, since the amendment facilitates the termination settlement greatly, sureties and guarantors would probably be quite willing to approve. In practice, this has not been a problem.

${ }^{103} \mathrm{PR}$ I5-912.I.

${ }^{204} \mathrm{PR}$ 15-912.2 sets forth a form of notice of termination to be sent by prime contractors to. subcontractors.

${ }^{105}$ See infra 481 . $\quad{ }^{108}$ See infra.474. 
or produced in connection with the contract. ${ }^{107}$ It cautions the contractor that he must review each of the statements from his subcontractors and suppliers and to make a recommendation, based on his negotiations with the subcontractor or supplier involved, as to the amount properly payable thereon. ${ }^{108}$ It also states that each such settlement is subject to the approval of the contracting officer.

The term "termination" is defined by PR I5-I50.9 as the discontinuance by the Government for its convenience of the contractor's right to proceed with the performance of the terminated contract, to the extent that it is terminated. On this basis, the contract is executory until the final settlement agreement ${ }^{109}$ is entered into. This has a distinct advantage over a termination of a contract which cuts off all of the rights and duties under the contract as of the date of termination, since it keeps alive all of the other provisions of the contract, such as those relating to advance payments, patents, disputes, anti-discrimination, etc., to the extent that they are applicable to the carrying out of the terms of the termination article and the termination notice. It also enables the contractor and the contracting officer to amend the contract, even after notice of termination, to include the standard form of termination article $e^{\mathbf{1 1 0}}$ or to make other modifications of the contract which may become necessary, and to rescind or modify instructions contained in the notice of termination from time to time with the consent of the contractor or where the contractor has not substantially changed his position in reliance upon previous instructions in a manner for which he cannot be compensated by termination charges. ${ }^{111}$

With the notice of termination the contractor also received a set of instructions with respect to the termination of the contract ${ }^{112}$ and a copy of TAM to assist him in the accounting phases of the termination. ${ }^{113}$ These instructions explain the necessity for the termination of contracts generally, state the War Department's intention to settle with the contractor in accordance with customary commercial practices and the terms of the termination article, and emphasize the necessity for prompt action in the preparation of inventories and the statement of costs. The instructions describe in detail the contractor's responsibilities under the termination notice and with respect to the claims of subcontractors and suppliers, and add the duty of notifying the contracting officer of any pending or subsequent legal procedures in connection with any subcontracts or purchase orders under the terminated contract. They also explain the preparation of inventories and include forms therefor. ${ }^{114}$ The steps to be taken to obtain partial payments on account of amounts due to the contractor and his subcontractors and supplies by reason of the termination are also included, ${ }^{115}$ as are the procedures with respect to post-termination expenses. The contractor is cautioned that whenever the termination article

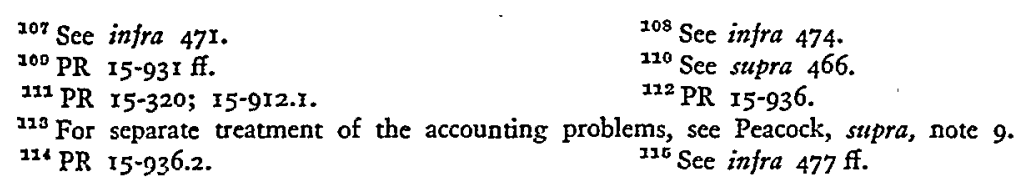


requires the approval of the contracting officer to any action of the contractor, the contractor should obtain written confirmation of any approval or instructions given orally. The instructions close with the statement that further advice as to procedure may be obtained if necessary. ${ }^{116}$

One of the most valuable steps in assisting the contractor to understand his rights, duties, and obligations in connection with the termination, and the procedures which should be followed by him in order to arrive at an expeditious and equitable settlement is the conference which is held with the contractor before ${ }^{117}$ or immediately after the service of the termination notice. ${ }^{118}$ At this conference the following important points are to be discussed:

I. The best effective date of the termination notice.

2. Work in process which should be completed.

3. Status of performance of the prime contract and subcontracts and purchase orders, in order to determine which of such subcontracts and.purchase orders should be completed.

4. Financial problems of the contractor and his subcontractors and suppliers which may arise by reason of the termination.

5. Procedures to be followed by the contractor in connection with the termination, with particular emphasis upon the following:

a. The immediate termination of subcontracts and purchase orders.

b. Obtaining cost statements, inventories, and settlement proposals from subcontractors and the review thereof.

c. Arranging a program for the disposition of property acquired for the terminated contract by the contractor and by or for his subcontractors and suppliers.

d. The preparation of a time schedule for the specific steps to be taken by the contractor, such as stop-work orders to his subcontractors and the furnishing of inventories, statements of costs, and proposals for settlement by the contractor and his subcontractors.

e. Where necessary, notification to employees, either orally or in writing, as to the reasons for the termination; and cooperation with the War Manpower Commission in determining the workers to be released and placing them elsewhere.

\footnotetext{
218 This statement suggests the problem of the extent to which a contracting officer or the members of his staff may assist a contractor in connection with a termination without violating 35 STAT. I Io7 (1909), I8 U. S. C. I940 ed. $\$ 198$, which makes it a crime punishable by a fine of not more than $\$ 5,000$ or imprisonment for not more than one year, or both, for any officer or employce of the United States to "act as an agent or attorney for prosecuring any claim against the United States, or in any manner . . . otherwise than in discharge of his proper official duties, (to) aid or assist in the prosecution or support of any such claim ...." (ital. added.) It is believed that any action taken by a contracting officer to explain termination procedures, to interpret the provisions of PR 15 and TAM, to furnish forms, to advise as to procedures and methods to be followed, or take any other similar action which would facilitate the negotiation of the settlement through a proper understanding of and compliance with PR 15 and TAM would be permissible under the above italicized language. This is due to the fact that it is the contracting offcer's duty, as part of his responsibility for the administration of the contract, to negotiate a settlement and determine the amount due quickly and efficiently. In this connection see PR I5-3I4, I5-322.

${ }^{117}$ PR $15-3$ I2.

${ }^{118} \mathrm{PR}$ I5-322.
} 
With these preliminary steps completed the contractor should be in a position to prepare his inventories, dispose of property, settle with his subcontractors and suppliers and negotiate a final settlement with respect to his terminated contract expeditiously and equitably.

\section{Disposition of Property ${ }^{110}$}

Perhaps the greatest single obstacle to the expeditious settlement of terminations is the disposition of raw materials, parts, supplies and work in process acquired or produced by a contractor and his subcontractors in connection with a contract and which are on hand at the time of termination of that contract. Of course, so far as the contractor and his subcontractors are concerned, the property could be disposed of readily by having the Government take title to it and simply remove it from their premises immediately upon termination, thereby putting the Government in the used property business on a gigantic scale. Before resorting to this step, however, the contractor and the subcontractors who originally acquired or produced the property first attempt to dispose of it in the regular course of their business. The provisions in the standard forms of termination articles dealing with the disposition of property are based on this premise. Under paragraph (a) of the old form the Government is obligated to take title to "all completed supplies ... a and partially completed supplies, work in process, materials, fabricated parts, plans, drawings, and information acquired or produced by the contractor for the performance of" the contract. However, it further provides that if "the contracting officer so directs or authorizes, the contractor shall sell at a price approved by the contracting officer, or retain at a price mutually agreeable, and such supplies, partially completed supplies, work in process, materials, fabricated parts or other things."120 Paragraph (b) (7) of the new form contains a similar provision requiring the contractor to "use his best efforts to sell." This fundamental policy of the Government's taking title to as little property as possible was expressly sanctioned and called to the attention of War Department contracting officers in a directive from Under Secretary of War Robert P. Patterson dated June 30, $1943 .{ }^{121}$ The directive also sets forth in clear and forceful language the importance of disposing of such property quickly so that it may be made available for use in essential war work at the earliest possible moment. It states that this purpose

119 For separate treatment of the property disposal problems see Mack, supra, note 25. As indicated supra 452, this is one of the problems now being actively considered by the Joint Contract Termination Board. What appears herein is therefore subject to any revisions necessitated by recent Board action. On February I5, 1944, in a report to the Director of War Mobilization, Mr. Baruch recommended that contractor-owned and Government-owned property be disposed of in the same manner; that the property be disposed of by the procuring agency, either directly or through the contractor, as promptly as possible, with full discretion as to price, subject only to general principles similar to those set forth in PR 15-358; and, if it is not so disposed of within sixty days, that it be removed by the procuring agency upon the demand of the contractor, after which the procuring agency may dispose of it for war production or, if xeclared surplus, dispose of it to a central agency, to be established for the purpose of taking over all such surplus property. Similar principles are to be applied to property in the hands of subcontractors of any tier. This recommendation was adopted immediately, and steps undertaken to put it into operation.

${ }^{120}$ See supra note 24 .

${ }^{121} \mathrm{PR}$ 15-350.2. 
can best be achieved by disposition of the property through the same industrial organization which acquired or produced it or through other recognized industrial channels, under the above-quoted authority in the termination article, and that the prompt and courageous exercise of this authority will result in the return of the property to use in war production. ${ }^{122}$ To allay the understandable apprehensions of contracting officers concerning the authorization of such sales the directive recognizes the inevitability of losses to the Government from such dispositions, in that such material must frequently be sold far below cost and, in the case of work in process, even at scrap prices. Unequivocally it says that contracting officers will "be supported in the exercise of their honest judgment" in carrying out this policy. This policy has since been forcefully reiterated by $\mathrm{Mr}$. Patterson in a letter dated December 28, 1943 .

The procedures providing for the disposition of property are designed to implement these purposes. The first step is to obtain inventories from the contractor and his subcontractors; ${ }^{123}$ the submission of partial inventories is encouraged where they will expedite the disposition of the property involved.124 One of the chief methods of speeding the sale of property is the grant of authorization to a contractor by the contracting officer in advance to make sales of specified types of property within stated discounts below cost. The contractor, at the discretion of the contracting officer, may grant similar authority to his subcontractors or suppliers. ${ }^{125}$ This avoids the necessity for prior approval by the contractor of each sale, which would otherwise be required under the provisions of the termination article, thereby eliminating a time lag which might frequently spell the difference between making and not making a sale. Of course, all sales are subject to the applicable regulations of WPB, OPA or any other Government agency having jurisdiction over the particular transaction involved. ${ }^{12 B}$ Since the contractor, in effect, is rendering a service to the Government by disposing of the property, he is not required to make any sale except for cash; any credit which he extends is expressly stated to be at his own risk. ${ }^{127}$ In addition to sales, provision is made for the disposition of property by retention by the contractor, subcontractor or supplier, ${ }^{128}$ or by return to the vendor. ${ }^{129}$ The contracting officer is empowered to authorize such retention or return at less than $\operatorname{cost},{ }^{130}$ where the amount to be credited is, in his judgment, reasonable.

The question of fixing such a reasonable value is a matter to be determined by the contracting officer, although to a large extent he must, of necessity, be guided by the opinions and recommendations of the contractor. ${ }^{131}$ While the contracting officer is legally in a position to approve any price he regards as reasonable, certain general standards are provided for him: ${ }^{132}$

\footnotetext{
222 The contractor's expenses in making such sales are reimbursable under paragraph (c) of the old standard form, Appendix C. $\quad{ }^{123} \mathrm{PR}$ 15-936.2.

${ }^{125}$ PR $15-359$.

${ }^{128} \mathrm{PR}$ i5-353.

${ }^{126}$ PR $15-362$.

${ }^{129}$ PR 15-354.

${ }^{124} \mathrm{PR}$ 15-351.3.

${ }^{127}$ PR $15-364$.

${ }^{130} \mathrm{PR} 15-354.2 ; 15-355$

${ }^{131}$ These will normally be included in the inventory. See PR 15-351.1; 15-351.2.

${ }^{132} \mathrm{PR} \times 5-358$.
} 
I. Type of property-standard parts, raw materials, critical items, work in process, scrap.

2. General market prices and conditions.

3. Location of property and cost of transporting and handling.

4. Utility of property to the Government if not disposed of.

5. Cost of storage and transportation to Government if not disposed of.

6. Necessity for speed of disposition to aid prompt settlement of terminated contracts.

In addition the contracting officer is urged to be "realistic about values"133 and to "give consideration to the present worth of the property"134 rather than to its cost, so as to enable the contractor to make an immediate sale.

On the question of the extent to which the Government will go in accepting responsibility for partially completed supplies, work in process, materials and parts which the contractor has on hand at the time of termination, both the old and the new standard forms, PR 15 and the Principles of Cost Determination are quite clear that this responsibility will be determined in the light of the reasonable requirements for the whole contract. Thus, paragraph (a) of the old form speaks of the Government's taking title to those items which were "acquired or produced by the contractor for the performance of [the] contract." Paragraph (b) (6) (i) of the new form requires transfer to the Government of title to all items "produced . . or acquired in respect of the performance of the work terminated." PR I5-495.5 excludes allowance of costs "in excess of the reasonable quantitative requirements of the contract." And paragraph 3 (d) of the Principles of Cost Determination makes this read "the entire contract." All of these appear to leave no doubt that inventory restrictions such as those appearing in WPB Priorities Regulation No. $I,{ }^{135}$ requiring inventories to be kept down to the "minimum working inventory reasonably necessary to meet deliveries," or the limitations of the Controlled Materials Plan permitting only a sixty day inventory, will not be applied to deny contractors reimbursement for inventory on hand, but that contracting officers will apply an overall standard of reasonableness as to the quantities which the contractor should have carried on hand judged, of course, in the light of the circumstances existing at the time of acquisition or production of the items involved, rather than at the time of termination. However, to the extent that the items on hand at the time of termination exceed a reasonable quantity as so determined, it is conceivable that the Government will not consider itself obligated to bear any losses resulting from the sale or retention of such excess quantities.

\section{Termination and Settlement of Subcontracts..$^{136}$}

As indicated above, simultaneously with the preparation of inventories and the development of a program for the disposition of property on hand at the time

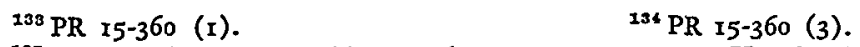

${ }^{185}$ Code of Fed. Regs., Title 32, Ch. 9, Part 944-14; C.C.H. War Law Serv. 130,901.23. 518 .

${ }^{130}$ For further treatment see Carter, Problems Arising Out of the Subcontractor Relationship, infra 
of termination, the prime contractor (hereafter referred to as the "contractor") is required by both standard forms of termination article to terminate immediately all his existing subcontracts and purchase orders, except as otherwise directed by the contracting officer. The War Department has provided a form of notice of termination to be used by contractors in terminating their subcontracts and purchase orders ${ }^{137}$ which to a large extent virtually duplicates the contents of the notice of termination to the contractor. However, in addition to requiring an inventory, a statement of cost and a proposal for a negotiated settlement, it cautions the subcontractor that because the amount due him on account of termination is a cost to the contractor to be reimbursed by the Government, his statement of cost may be subject to Government audit and the items listed in the inventory may be subject to Government inspection. ${ }^{138}$ It also informs the subcontractor that, with the approval of the contracting officer, partial payment on account of amounts due to the subcontractor will be made whenever he and the contractor agree that at least the amount of the proposed payment is clearly due to him..$^{130}$

The task of settling the claims of subcontractors, vendors and suppliers (hereafter referred to as "subcontractors") upon such termination is a responsibility of the prime contractor. ${ }^{140}$ This is the result of an apparently deliberate policy on the part of the War Department to remain apart from the relationship between a contractor and his subcontractors. Thus, no form of termination article for sub. contractors or purchase orders has ever been prescribed; in fact there has never been a requirement that any termination article be included in subcontracts or purchase orders. ${ }^{141}$ The Government appears to regard the relationship between a contractor and a subcontractor as a purely commercial relationship, so that the matter of termination is merely another subject for negotiation between them. Consequently the Government is undoubtedly justified in taking the position that, on termination, the contractor in the first instance should collect and review the cost statements and negotiate the settlements with his subcontractors. This, however, in no way infringes upon the Government's right to review the settlements arrived at by the contractor, in view the fact that the cost of such settlements ultimately will fall on the Government. ${ }^{142}$ While paragraph (c) of the standard forms of termination articles, which is the basis for the negotiated settlement, does not require approval by the contracting officer of settlements arrived at by a contractor with his subcontractors, paragraph (d) of the old form, which sets forth the basis for settlement by formula, does make this requirement. In the new form, paragraph (b) (5) authorizes the contracting officer to require such approval. During the process of arranging settlements with subcontractors, there is no assur-

\footnotetext{
${ }^{287} \mathrm{PR}$ 15-912.2.

${ }^{188}$ This would undoubtedly furnish an adequate basis for a prosecution under 52 STAT. 197 (1938), I8 U. S. C. $1940 \mathrm{ed}$. 580 of any subcontractor who furnished a fraudulent statement or one which he knew to be false, since it makes it clear that the statement is ultimately to be presented to the Government. See PR 15-410 for the form of certificate.

${ }^{139}$ See infra 478.

${ }^{141}$ House Hearings 35.

${ }^{110}$ PR 15-325.1.

${ }^{142}$ See PR 15-421.3; 15-437.
} 
rance that ultimately the contracting officer and the contractor will arrive at a negotiated settlement. Therefore a contractor would be well advised to secure the contracting officer's approval to each settlement arranged by him with any of his subcontractors, even if it is anticipated that a negotiated settlement will be arrived at, since, in the absence of the negotiated settlement, a formula settlement is the only recourse. However, a contracting officer is authorized to permit a contractor to make settlements of subcontracts within stated limits without first securing the contracting officer's approval for each settlement. ${ }^{143}$ A contracting officer is further urged not to require further approval of settlements with second tier and more remote subcontractors, but merely to approve them after they have been made unless any particular settlement appears to have been made in bad faith. ${ }^{144}$

The termination of any subcontract will, of course, be controlled by the terms of the termination article, if any, contained therein, including the terms applicable to the measure of damages to be paid to the subcontractor by reason of the termination. $^{145}$ In the absence of any termination provision in a subcontract, the subcontractor would be entitled as a matter of law, to the common law measure of damages-loss of full anticipated profit- ${ }^{146}$ since the termination of the contract would be tantamount to a breach. ${ }^{147}$ As a practical matter, however, the experience in World War I and in terminations settled thus far during this war indicates that most subcontractors will not insist on this legal right, but will settle on the basis of reasonable reimbursement for costs, plus profit on the work done with respect to the uncompleted portion of the subcontract.

In addition to this profit element a subcontractor is entitled to be paid an amount adequate to compensate him for his costs in connection with the uncompleted portion of his subcontract. Hence he is required to submit to the contractor a statement of such costs as a basis for a negotiated settlement, ${ }^{148}$ and the contractor is required to review each of such statements in the first instance. ${ }^{149}$ In. making such review he is expected to exercise the standard of scrutiny which a businessman would apply in the conduct of his own affairs, ${ }^{150}$ but he is not required to warrant the accuracy of the facts presented in such statement by the subcontractor. ${ }^{151}$ While PR ${ }_{15}$ has no provision with respect to this question, it is arguable that on the basis of this standard a contractor would not be required to assert every legal defense available to him in order to reduce the amount due to the subcontractor, but would be permitted to waive such defenses in any situation in which a reasonable businessman might be expected to do so in negotiating

${ }^{163} \mathrm{PR}$ 15-325.2(3).

14 House Hearings 35 .

${ }^{117} \mathrm{Td}$.

${ }^{110}$ PR I5-43I.

${ }^{144} I d$.

${ }^{140} \mathrm{Id}$. at 35,36 . See also supra 466 .

148 See PR 15-912.2.

${ }^{150} \mathrm{PR}$ 15-432.

${ }^{151} \mathrm{PR} 15-440$ sets forth the form of certificate to be signed by a contractor in submitting subcontractors' termination charges. Under it he certifies that he has examined such charges and that in his opinion "the settlement .... is fair and reasonable, is proposed in good faith and is not more favorable... than one which the (contractor) would make if reimbursement by the Government were not involved." 
with a subcontractor with respect to the termination of a contract in the ordinary course of his own business.

In the case of every statement submitted by a subcontractor, a minimum scrutiny by the contractor would necessitate an office review by qualified accounting personnel. ${ }^{152}$ Based on such office review it is the contractor's responsibility to determine whether any further examination of a particular statement is required in the light of the following considerations: $:^{153}$

r. Amount and complexity of proposed settlement.

2. Findings as a result of the office review.

3. Available reports of independent public accountants.

4. Any information available from the contractor's personnel who have had contacts with the operations under the subcontract.

Such further review may take any of the following forms:

I. Additional data or explanations in writing from the subcontractor.

2. Contractor's accounting personnel may discuss the statement with the subcontractor.

3. A selective audit may be made of subcontractor's accounting data on which his statement was based.

Upon approval by the contractor of each statement from the subcontractor it is to be submitted immediately to the contracting officer for his review so as to expedite approval of the settlement and of the contractor's own statement of cost, of which each settlement with a subcontractor will necessarily be a part.

The importance of the contractor's examination and review of his subcontractors' statements should not be minimized. While the Government reserves the right to make its own check of such statements, as a practical matter it will undoubtedly rely to a very great extent on the contractor's review, because of the sheer volume of work which a review by the contracting officer of each settlement with a subcontractor would entail. As a matter of fact, the contracting officers are authorized to do just that in the case of subcontract settlements reviewed and certified by contractors in whom "they have confidence and in the absence of circumstances coming to their attention pointing to the necessity of special investigation of particular subcontractors' claims or showing incompetent or inadequate review by the prime contractor."154 Undoubtedly this authority will go a long way toward achieving expeditious disposition of termination settlements of subcontracts.

Where, however, a contractor and a subcontractor cannot agree upon a settlement satisfactory to the contracting officer, the amount due to such a subcontractor may be excluded from the negotiated settlement between the Government and the contractor, reserving for a later time the question of the amount to be paid to the contractor in connection with such a subcontract. There is also authority under which the Government may assume and agree to pay the obligation of a contractor 
with respect to such a subcontract, so far as it is related to the uncompleted portion of the terminated contract. ${ }^{155}$ In such a case the contracting officer would then undertake to negotiate a settlement directly with the subcontractor and would undoubtedly be authorized to follow any of the procedures set forth in $\mathrm{PR} I 5$ in arriving at such a settlement.

\section{Interim Financing for Terminated Contractors ${ }^{156}$}

No reasonable termination procedure having due regard for the necessary protection of the Government's interests could be devised which would be immediate and self-executing in its operation. Inevitably there will be an appreciable time lag between the service of the notice of termination and the payment finally agreed upon by the contracting officer and the contractor in final settlement of the termination. It is this time lag which creates one of the greatest practical problems arising out of contract termination: How are contractors and subcontractors to be provided with funds quickly in order to replace the working capital tied up in their terminated contracts or subcontracts so as to enable them to turn to other war work or to civilian work immediately? Without such funds it is inevitable that their facilities will lie idle and their employees will be lost to them, since most war producers now have insufficient reserves to carry on without the use of some portion, at least, of their working capital which is presently invested in war work. ${ }^{157}$ The War Department recognizes this problem ${ }^{\mathbf{1 5 8}}$ and is committed to a program for meeting it by making prompt partial payments to contractors on account of amounts due to them and their subcontractors in connection with termination settlements, by utilizing available advance payment balances for the same purpose $^{150}$ and by liberalization of the use of guaranteed loans. To further implement this program it recommended legislation which opened the whole subject of terminations to protracted hearings. ${ }^{160}$

Such partial payments are authorized by paragraph (i) of the old standard form of termination article and by paragraph (g) of the new standard form, and may therefore be made upon request of the contractor under-any contract which contains that article, either originally or by amendment. The only restrictions on such partial payments are that the contracting officer and the contractor must agree that at least the amount of the proposed partial payment is due and that that amount is payable without prejudice to the determination of any of the other items in the termination. ${ }^{161}$ This gives a contracting officer the necessary leeway to make partial payments quickly, since he need require only such evidence as to the amounts of such partial payments as he considers proper, ${ }^{162}$ and since in many cases it can readily be determined that some minimum amount will in any event

\footnotetext{
${ }^{205} \mathrm{PR}$ 15-535.

${ }^{150}$ For a detailed treatment of the financing problems, see Cleveland, supra, note $3 \mathrm{I}$.

${ }_{107}$ National City Bank Letter, March I943, 30, 35.

${ }^{108} \mathrm{PR} 15-500$.

${ }^{150}$ Id.

${ }^{100}$ See infra $500 \mathrm{ff}$. For a discussion of the proposed legislation see Cleveland, supra note 3I.

${ }^{261} \mathrm{PR}$ 15-501.2. ${ }^{162} \mathrm{PR}$ 15-501.3.
} 
be due to the contractor. ${ }^{163}$ In making his determination a contracting officer need not make any exhaustive audit and is entitled to rely on any available data which has been certified to by independent public accountants. ${ }^{104}$ Where he deems such action necessary to protect the interests of the Government he may impose any or all of the following conditions: ${ }^{165}$

I. Submission of a partial statement of costs and termination charges certified as correct by at least two duly authorized officers of the contractor.

2. A statement by the contractor that the proposed payment has not been assigned or that the assignee has consented in writing to the payment.

3. A statement by the contractor that all statements of fact and representations made are true and correct and that they are made subject to the penalties provided in I8 U. S. Code 80.

Any amounts so paid may of course be used by a contractor to make partial or full payments to some or all of his subcontractors. While the Government cannot make such partial payments directly to subcontractors, ${ }^{166}$ wherever a contracting officer wishes to assure that a partial payment in a definite sum will be made to a particular subcontractor (thereby achieving the same result), he may do so by means of a supplemental agreement ${ }^{167}$ entered into by the Government, the contractor, the subcontractor who is to receive the partial payment and any intermediate subcontractors, and providing that:

I. All of the parties agree that the payment may be made.

2. It is within the amount clearly owing to the subcontractor who is to receive the payment as well as to the prime contractor and any intermediate subcontractors.

3. The parties warrant that no setoffs or counterclaims are outstanding against the subcontractor who is to receive payment.

4. All of the parties make a 'release for the benefit of the Government to the extent of the payment made.

The payment is then made to the contractor but on account of, and in trust for, the subcontractor who is ultimately to receive it. In appropriate cases less formal arrangements may also be devised so long as the contracting officer believes that they will adequately protect the Government, particularly with respect to set-offs or counterclaims which may exist against the subcontractor who is receiving the partial payment. ${ }^{168}$

In addition to partial payments, advance payments previously authorized in connection with the terminated contract may be used to furnish funds to the contractor, provided the contracting officer finds that the amount of such proposed payment out of an available advance payment balance, in addition to the advances previously made but not yet liquidated by deliveries, will not exceed

\footnotetext{
${ }^{103}$ Thus a very brief survey of a terminated contract might reveal that the termination charges would clearly exceed $X$ dollars. An immediate payment of $X$ dollars would then be authorized.

104 PR I5-501.3.

106 The reasons are set out in PR 15-502.1.

${ }^{107} \mathrm{PR} 15-502.2(2)$. The form is set out in PR $15-921$.

${ }^{168} \mathrm{PR}$ 15-502.2(3).
} 
the total estimated termination charges. ${ }^{169}$ This provides another source of funds readily available to tide the contractor over and help him retain his status as a going concern despite the fact that all or some of his contracts may have been terminated.

With respect to the utilization of guaranteed loans, the war procurement agencies have announced ${ }^{170}$ that hereafter such loans will be made available to contractors in order to free their own working capital previously invested by them in war contracts, upon the termination of such contracts. In such cases the lending bank will be required to have some participation in the loan and the loan agreement will provide that in the event of termination the contractor will be entitled to a loan based on a stated percentage of inventory, work in process, accounts receivable and amounts paid or due to subcontractors by reason of the termination. Subcontractors will benefit also because contractors will be required to pay to subcontractors whatever is due them when such obligations are used as part of the basis for the loan. The avowed purpose of this extension of the guaranteed loan is to prevent that lag in war production which might be caused by contractors' fears that their working capital will be tied up for a considerable length of time in the event of termination. While this plan undoubtedly has merit its utility, from the point of view of the speed with which the loan will be made, will depend on the extent to which the lending bank will require supporting data for the contractor's statement as to the amount of his inventories, work in process, accounts receivable and obligations to his subcontractors, on the total of which the amount of the loan will be based.171 Probably this, to a large extent, will depend on the lending bank's general experience with the prospective borrower as a credit risk, so that contractors in a less favorable financial position who require assistance in the way of working capital will have greater difficulty in obtaining such loans. The avoidance of this paradoxical result is the principal problem facing the administration of this device, but it is doubtful whether much can be done in this regard so long as commercial banks are required to participate in the loans. The elimination of this paradox is one of the principal purposes of the proposed legislation previously mentioned.

To the extent that these methods of interim financing are used expeditiously and courageously, war producers will be made always available for war work other than that which has been terminated, or failing that, for necessary civilian production. It is doubtful, however, whether the interim financing problem can be solved without some direct Government assumption of risks, loans and purchase of subcontractual claims, as contemplated by the proposed legislation. ${ }^{172}$

\footnotetext{
${ }^{160}$ PR $15-503$.

${ }^{170}$ Federal Reserve Bank of New York, Circular No. 2681, September $x$, 1943, OWI Release No. 2424, September I, 1943, C.C.H. War Law Serv. $\llbracket 29,176$.

${ }_{171}$ Federal Reserve Bank of New York, Circular No. 2691, September I3, r943, states that a lending bank "will have sufficient incentive to exercise reasonable care to obtain additional verification in those cases where that appears to be necessary."

${ }^{172}$ See Cleveland, supra, note $3 \mathrm{I}$.
} 


\section{Negotiation of the Settlement with the Contractor}

Since the negotiation of the settlement in connection with the termination of a contract is the exercise of a right granted by the terms of the contract rather than a determination of the actual costs, it is probable that as a matter of law the contracting officer, acting on behalf of the Government, could agree to a settlement at any amount up to the total contract price (less payments for completed supplies) and his settlement could not be challenged short of proof that he had acted unreasonably or fraudulently. ${ }^{173}$ PR ${ }_{15}$ expressly recognizes this broad discretion in the contracting officer. Thus PR $15-53$ xays that "in determining a proper settlement under the standard termination article for use in lump sum contracts (PR 324) providing for a negotiated settlement of the uncompleted portion of the contract [he] is given a very wide range of discretion and may act upon such evidence as is satisfactory to him under all the circumstances, with a view to reaching a fair adjustment expeditiously and with a minimum of technicality. He may allow the contractor by way of settlement such amount as will, in his judgment, give to the contractor fair, full and reasonable compensation for the contractor's costs, expenditures, liabilities and commitments incurred in connection with the uncompleted portion of the contract, together with such reasonable allowance for profit on the uncompleted portion of the contract as the contracting officer deems just and equitable and as affording to the contractor, under all the circumstances, such profit as the contractor has actually earned by work in fact done on the uncompleted portion of the contract." PR $15-532$ contains the following language:

"The negotiated settlement gives the contracting officer maximum flexibility in working out with the contractor a fair settlement of the amount due on the uncompleted portion of the contract under the standard termination article (PR 324) for use in lump sum supply contracts."

However, PR I5 also recognizes that no contracting officer should negotiate any settlement without the benefit of all the relevant information which can be secured, both for his own protection and for the protection of the Government's interests. For this reason PR $15-445$ states:

"In negotiating a settlement, the contracting officer should have as a guide an accounting memorandum, prepared by Government accounting personnel, containing the available accounting .data as to the costs incurred by the contractor with respect to the uncompleted portion of the contract and computations based upon such data and other available information as to the rate of profit which it is expected the contractor would have earned if he had been permitted to complete the contract."

To this PR 15532 adds:

"To arrive at . . . a fair settlement ... the contracting officer will make use of all relevant and available guides as to what constitutes an equitable amount to be paid to the contractor."

${ }^{173}$ See SPJGC $1943 / 10938$, August 24, 1943, citing, inter alia, Alprin v. Huffman 49 F. Supp. 337 (I943); U. S. v. Village of Farmingdale 43 F. Supp. 561 (I94I), aff'd r29 F. (2d) 678 (I94I); Marbury v. Madison 5 U. S. 137,166 (1803). 
Nevertheless these provisions expressly restrict the function of such accounting data or guides by providing that none of them limit or control a contracting officer in arriving at a negotiated settlement, but are to assist him in arriving at a proper determination of the amount of such settlement. ${ }^{174}$ Instructions for the preparation of such advisory data by Government personnel in connection with the negotiated settlement ${ }^{\mathbf{1 7 5}}$ are set forth in TAM, which also emphasizes that the information so provided will not limit the contracting officer in the negotiation of the settlement. ${ }^{170}$

However, while the contracting officer is given this broad range of discretion in negotiating the settlement, among the chief aids to which he is referred for the principles to guide him in the negotiations are the terms of the formula set forth in the standard form of termination article. ${ }^{177}$ As a practical matter, therefore, it is highly likely that, in the absence of unusual circumstances, a negotiated settlement will result in the payment of an amount which will not be very much different from what would have been paid had the formula been strictly applied. Since the terms of the formula state "fair, general principles"178 for determining what the contractor should receive, both the contracting officer and the contractor will realize that if they guide themselves by it their negotiations will be free from any subsequent criticism.

The basic document on which the negotiation is based is the contractor's proposal for settlement. ${ }^{179}$ This consists of three types of statements, including (I) the costs incurred by the contractor with a statement of his profit thereon, (2) the subcontract termination charges and (3) the contractor's post termination expenses. As set forth in the instructions which a contractor receives when his contract is terminated, ${ }^{180}$ it is the contractor's responsibility to submit these statements or any part of them as promptly as possible. These statements, together with their supporting schedules are required to be certified by the contractor as true and correct, ${ }^{181}$ and constitute his basic representations with respect to the determination of the amount to be paid him in connection with the termination. As such they are subject to the penalties for false or fraudulent statements or representations in connection with claims against the United States. ${ }^{182}$ Upon receipt of such proposal, or any part thereof, it is the responsibility of the contracting officer to determine the extent to which Government accounting personnel will review it. ${ }^{183}$ Detailed auditing is to be kept to a minimum ${ }^{\mathbf{1 8 4}}$, and reliance is to be placed

174 See PR 15-109.

175 See PR $\times 5-421.2$.

176 TAM II00.I.

${ }^{177} \mathrm{PR}$ 15-443.3, $15-450$. For a discussion of the formula settlement see infra $490 \mathrm{ff}$.

${ }^{278} \mathrm{PR} \quad 15-450$.

${ }^{180} \mathrm{PR}$ 15-936.

${ }^{178}$ House Hearings 42.

${ }^{183}$ See 52 STAT. 197 (1938), 18 U. S. C. 1940 ed. $\$ 80$.

${ }^{183}$ Sce Peacock, supra, note 9.

${ }^{184}$ In the interests of keeping the audit work to a minimum PR $15-552$ suggests the feasibility of settling several terminations with the same contractor at once. This raises the whole problem of the practicability of an overall company settlement with a particular contractor by the Government with respect to all of his terminated work, on prime contracts and subcontracts. See Hotsse Hearings 157; Senate Hearings 15. 
instead upon an intelligent review of the data presented by the contractor. ${ }^{180}$ In any event, however, at least an office review is required in every case as the minimum protection of the Government's interests. ${ }^{186}$ Such a review is intended to place special emphasis on the following: ${ }^{187}$

I. A determination of whether each item appears proper in the light of the applicable cost definitions. ${ }^{188}$

2. Reasonableness of each item in relation to other items and to the stage of completion.

3. Reasonableness of quantities of material and work in process on hand.

4. Reasonableness of rate of overhead.

5. A determination of whether any of the materials and other items appear to be "common items."189

6. A determination of whether the statement appears to have been prepared in accordance with standard accounting practices.

7. Verification of mathematical accuracy of the statement and supporting schedules.

8. Verification of the accuracy of information furnished in connection with outstanding guaranteed loans and advance payments and schedules of completed units.

After completion of this examination the contracting officer, in consultation with his accounting personnel, may desire a further accounting check, in one of the following forms: $:^{190}$

I. Additional data or explanations may be requested in writing from the contractor.

2. Government accounting personnel may discuss the statement with the contractor.

3. A selective audit may be made of the contractor's accounting data on which his statement was based.

The results of the accounting examination of the contractor's proposal for settlement are to be incorporated in a report to the contracting officer ${ }^{101}$ which will summarize the costs of the contractor and (I) show separately any relatively large costs arising from unprocessed raw materials, (since these may represent no substantial work on the part of the contractor) and unusual costs; (2) comment on the basis for the determination of the allowance for profit to the contractor; and (3) suggest any items meriting special consideration by the contracting officer. This report, together with the contractor's proposal for settlement, will generally give the contracting officer adequate information on the basis of which to undertake negotiations with the contractor.

The most difficult item to determine in the negotiation of the settlement is that

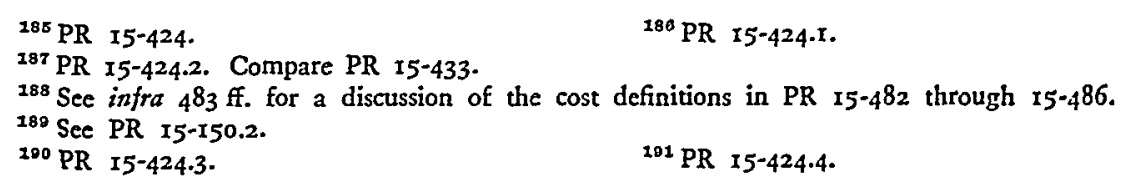


covered by paragraph (c) of the standard forms of termination articles, the amount to be paid to the contractor to compensate him for his costs and anticipated profit with respect to the uncompleted portion of the contract. Two alternative methods are provided by which the contractor may determine these costs. One of these is the so-called "Inventory Method."192 Under this method these costs are determined by a detailed pricing of the inventory on hand at the time of termination. To the total is added the profit allowance. This method has utility in those cases where the inventory consists principally of purchased materials on which relatively little work has been done, or where accurate unit cost data is available with respect to the work in process. The other method is the so-called "Total Cost Method"193 and is for use where such accurate unit cost information is not available. All costs incurred up to the time of termination are totaled and a profit allowance on all of such costs is added. From this sum is deducted the total contract price of all completed items. The result represents the contractor's costs and profit with respect to the uncompleted portion of the contract. This method is particularly useful in situations where it is difficult to separate the costs as between the completed and the uncompleted portions of the contract.

In addition to the determination of the cost and profit with respect to the uncompleted portion of the contract the contractor's proposal contains a statement of the amount due for completed items, the total of the subcontractor's termination charges and the costs incurred after the date of termination. This last item is also determined by negotiation, pursuant to paragraph (e) of the old standard form of termination article, and is presumably included within paragraph (c) of the new standard form. In addition, deductions are made for credits resulting from the sale or retention by the contractor of items of inventory and for miscellaneous offsets and deductions, such as the contract price for supplies which are undeliverable because of destruction or damage, any unsettled claims of subcontractor against the contractor, and any other claims which the Government may have against the contractor.

To aid in the negotiations with respect to the allowable costs on the uncompleted portion of the contract and to assist in the review of contractors' statements of costs, as well as to state the basis for determining actual costs in the case of a formula settlement, PR I5 contains the Principles of Cost Determination promulgated by the Office of War Mobilization on January 8, I944. ${ }^{104}$ These Principles are stated expressly to be applicable only to the formula settlement under the new form, ${ }^{195}$ and the negotiated settlement provision of the new form expressly states that the formula provision shall in no way "be deemed to limit, restrict or otherwise determine or affect the amount or amounts which may be agreed upon to be

${ }^{102} \mathrm{PR} 15-446(\mathrm{r})$. $\quad{ }^{103}$ PR $15-446(2)$.

${ }^{104}$ PR 15-482 through 15-486; Appendix B, infra, p. 00. These Principles have been substituted in PR 15 for the cost definitions previously set forth in PR 15-48I through PR 15-496.

${ }^{105}$ Appendix A, infra 508, par. (h). It has been administratively determined that the new Principles arc applicable as guides in connection with settlements negotiated under the old form. 
paid to the contractor" under the negotiated settlement provision. ${ }^{100}$ Nevertheless contracting officers by and large are practical, hard-headed people and it would be surprising indeed to find them not being guided by these Principles in negotiating with contractors the amounts to be allowed on termination settlements, although feeling free at any time to disregard them where the circumstances warranted such action.

The Principles are intended to cover the costs which are recognized under commercial accounting practices, including direct and indirect manufacturing, selling and distribution, administration and other costs incurred which are reasonably necessary for the performance of the contract and are expressly allocable to the terminated portion. ${ }^{197}$ Although a number of cost items are specifically enumerated, the enumeration is not to be regarded as all-inclusive, and the failure to mention any cost specifically is not intended to imply its inclusion or exclusion as a cost in any particular case. ${ }^{198}$

To the extent to which such costs are allocable to the terminated portion of a particular contract, the Principles authorize the allowance of the cost of inventory items which are common to the terminated contract, and other work of the contractor; ${ }^{199}$ claims of subcontractors which are common to the terminated contract and other work of the contractor; ${ }^{200}$ depreciation on machinery, buildings and equipment (including normal obsolescence); ${ }^{201}$ experimental and research expenses; ${ }^{202}$ engineering and development and special tooling costs, subject to the requirement that the contractor protect any interest of the Government therein by a transfer of title-or other appropriate means; ${ }^{203}$ an allocable portion of rental under leases necessary for the performance of the contract, plus reasonable alteration and restoration costs, and less the residual value of such leases, and subject to the contractor's having made reasonable efforts to reduce the cost of such leases by termination, assignment, settlement, etc. ${ }^{204}$ advertising; ${ }^{205}$ interest on borrowings; ${ }^{206}$ reasonable accounting, legal, clerical and other expenses in connection with the termination and settlement of the contract and the subcontracts thereunder; ${ }^{207}$ storage, transportation and other costs incurred for the protection of or in connection with the disposition of property acquired or produced for the contract, ${ }^{208}$ and the initial, or "starting load" costs. ${ }^{209}$ These are non-recurring costs arising from unfamiliarity with the product, which must be met in the early stages

${ }^{190} \mathrm{Id}$. at (c).

${ }^{197}$ PR 15-482, Principles, Appendix B, infra 511, par. I.

${ }^{108}$ PR 15-486, Principles, paragraph 5.

${ }^{180}$ PR 15-482(a), Principles, paragraph I(a).

${ }^{200}$ Id. at (b).

${ }^{202}$ Id. at (d).

${ }^{204} I d$. at $(\mathrm{g})$.

${ }^{201} 1 d$. at (c).

${ }^{203}$ Id. at (c).

${ }^{200}$ Id. at (h).

${ }^{200} \mathrm{Id}$. at (j). Under the previous cost definitions such interest was allowed only where the proposed settlement was on a non-profit basis. This change is undoubtedly due to the fact that the percentage of profit permitted by paragraph (d)(2) of the new standard form of termination article, the formula provision, is limited to $6 \%$.

${ }^{207}$ Id. at $(k)$.

${ }^{200}$ PR $15-483$, Principles, par. 2.

${ }^{208}$ Id. at (1). 
of production although the benefits from such expenditures continue to accrue throughout the life of the contract. Thus, a high rate of rejects or machine breakdowns in the early stages of production under a contract should not be charged only to supplies completed during that period but should be apportioned over the whole life of the contract, since the experience acquired during that early period contributes to more efficient production during the remainder of the contract and some portion of such costs is therefore fairly chargeable to the remainder of the contract.

In keeping with the intention to include in the determination of costs only those costs which are properly allocable to the uncompleted portion of the terminated contract, certain costs are expressly excluded, although such express exclusion is not intended to indicate that these are the only excluded costs. These excluded costs are losses on other contracts, fees and other expenses not directly related to the terminated contract, losses on investments, provisions for contingencies, and premiums on life insurance where the contractor is the beneficiary; 210 expenses of converting the contractor's facilities to other uses; ${ }^{211}$ expenses caused by the contractor's negligent or wilful failure to discontinue work within a reasonable time after the effective date of the termination notice; ${ }^{212}$ costs incurred because of materials or services purchased or work done in excess of the reasonable quantitative requirements of the entire contract; ${ }^{213}$ and a provision excluding costs which have previously been charged off during a period covered by a previous renegotiation under Section 403 of the Sixth Supplemental National Defense Appropriation Act, 1942, as amended, ${ }^{214}$ if a refund of excessive profits was made, or to the extent that the charge-off avoided a refund.215

The necessities of the war production program have inevitably required construction and acquisition of numerous facilities on which an allowance of normal depreciation $^{216}$ would be inadequate in the event of termination of a contract with respect to which they were constructed or acquired. Typical of this situation of "war time obsolescence" is the special purpose tool which has no use apart from the manufacture of an item the contract for which has been terminated. An example is the $\$ I I, 000$ machine described in the hypothetical case discussed in the introduction. To say that a contractor should not be compensated beyond a normal rate of depreciation for such a special purpose tool would result in a considerable impairment of the willingness of contractors to attempt to develop new and more efficient special purpose machinery. The general purpose tool which :

${ }^{210}$ PR $\times 5-484(a)$, Principles, par. (3)(a).

211 Id. at (b).

${ }^{213}$ Id. at (d). See supra 473 .

${ }^{212} I d$. at (c).

214 Pub. L. No. 528, 77th Cong., 2d Sess. (April 28, 1942), $\$ 403$, as amended.

320 This rule had been adopted and applied by some contracting officers prior to its inclusion in the Principles, but it is well to have it expressly stated and made uniform. It is clearly fair and proper, being based on the fact that the charging-off of such costs decreased the amount of the refund by the amount of such costs so that, in effect, the charge-off represented reimbursement of such costs already made to the contractor.

${ }^{210}$ See PR $15-482(c)$. 
contractor purchases solely for the manufacture of an item the contract for which is subsequently terminated is also in this category. For such cases a contracting officer is authorized to include an amount which bears the same proportion to the total loss of useful value as the deliveries on the terminated portion of the contract bear to the total deliveries which have been made and would have been made had the contract and any other contracts involved been completed. "Loss of useful value" would appear to mean original cost, less depreciation already taken for income tax purposes, and less residual value, if any. The remainder is then prorated between the completed and terminated portions of the contract. ${ }^{217}$ The net effect of this is to prorate the residual value in the same way, thereby resulting in a larger payment to the contractor. The argument in favor of this approach is that under sound principles of cost accounting the facility would have been charged to the contract at cost less residual value when the contractor first fixed his price.

To be entitled to the inclusion of such an item as a cost, the contractor must protect the interests of the Government in such a facility by transferring title thereto to the Government, or by such other means as the contracting officer may consider appropriate. To prevent a windfall to the contractor and to require him to bear the same burden with respect to such facilities which he would have borne had the contract been completed, the total allowance for the cost of experiment and research, engineering and development, special tooling designed and purchased or produced for the contract, "war time obsolescence," loss on leases, and advertising is properly limited to an amount which does not exceed the total contract price if the contract had been completed, less all other costs which the contracting officer estimates would have been necessary to complete the contract. ${ }^{218}$ Without this limitation a contractor, on termination, might conceivably receive more for such items than would have remained to cover them out of the total contract price if the contract had been completed.

Perhaps a more desirable method of determining the amount of the allowance to a contractor in cases of "war time obsolescence" would be to deduct from the original cost of the facility involved, the actual depreciation allowed or allowable thereon in the price of supplies completed or to be completed under the contract ${ }^{210}$ and from the remainder to deduct the residual value of the facility. The resulting amount would be the true loss of value in the facility and could properly be charged as a cost with respect to the uncompleted portion of the contract. Crediting the residual value in this manner would eliminate the necessity for the Government's taking title to the facility or for any other means of protecting the Government's interests, since the Government would then have no such interests. Such residual value, of course, would be determined in the light of a number of factors, includ-

${ }^{217}$ PR 15-482(f); Principles, par. I(f).

218 Id. at (i).

${ }^{210}$ Since the underlying purpose of the standard form of termination article is to reimburse the contractor for all his costs with respect to the uncompleted portion of his contract it would seem proper to allow actual depreciation, rather than the rate of depreciation originally included in the contract price. 
ing the market value of the facility, its usability for other work by the contractor or others, the extent to which it has enhanced the value of the contractor's capital assets, the use to which he has actually put it since termination and other similar considerations. Thus the question of whether the facility had a general or special purpose would automatically be taken into account, and, even more important, maximum utilization of the facility would be fostered since, if the contractor could not use it himself, he would immediately dispose of it to some one who could use it in order to realize his investment in it and recover the residual value which had been deducted in determining the amount of allowable costs for the facility in connection with the termination.

The other part of the amount to be paid to the contractor with respect to the uncompleted portion of the contract under paragraph (c) of the old standard form of termination article is "such allowance for anticipated profit with respect to such uncompleted portion of the contract as is reasonable, under all the circumstances." Purely as a matter of a contracting officer's legal authority based on a construction of this contractual language, it is arguable that he could allow to a contractor any amount up to the full common law damages of anticipated profit on the whole portion of the contract with respect to which the contractor's right to perform has been terminated irrespective of the extent to which he had performed any work or rendered any services with respect to such uncompleted portion. ${ }^{222}$ However, the War Department has very definitely adopted the policy of permitting its contracting officers to make such allowance for profit only to the extent of "work actually done by the contractor and materials actually obtained or furnished. It is not intended that the contractor shall be allowed any profit with respect to work which has not been done."223 Clearly, the War Department may limit the authority of its contracting officers in this manner, since this is merely a restriction on the scope of such authority and in no way infringes upon any contractual or other right of a contractor whose contract contains the standard form of termination article. The negotiated settlement provision of that article (paragraph [c]) provides merely that the amount to be allowed for anticipated profit with respect to the uncompleted portion of the contract shall be part of a sum to be agreed upon by the.contracting officer and the contractor and that it shall be "reasonable under all the circumstances." If, in the light of competent instructions issued to him, a contracting officer cannot agree with a contractor on the allowance for profit, they have their recourse to the formula provision of the standard form of termination article ${ }^{224}$ for the determination of the amount to be paid to the contractor with respect to the uncompleted portion of the contract. This provision clearly limits the allowance for profit to a profit on work actually

\footnotetext{
292 On the other hand, the language of paragraph (c) may well be interpreted to relate only to that part of the uncompleted portion on which any work has been done or costs or liabilities incurred. Especially is this so in light of paragraph (d), which is clearly so restricted and which, in effect, is merely a substitute for (c).

${ }_{223}$ PR 15-449. See 15-443.2 and 15-531; House Hearings 43, 44.

324 See Appendix C, par. (d), infra 515. For a discussion of the formula settlement see infra $490 \mathrm{ff}$.
} 
done. The contractor, having contracted for this alternative procedure where there is no agreement as to allowance for costs and profit with respect to the uncompleted portion of the contract, cannot object to a resort to it. ${ }^{225}$ Undoubtedly the same principles would apply to a negotiation under paragraph (c) of the new standard form.

The possibility that a contractor in a particular case might successfully maintain that this restriction on a contracting officer's authority to determine the profit allowance by negotiation is unreasonable or arbitrary is probably so remote that it may be disregarded for the purpose of this discussion. In fact the restriction is far from unreasonable. It is undoubtedly based on the premise that a contract for any of the implements necessary to wage the war is not an ordinary business transaction; it is part of a war for survival in which all must play their part and share their portion of the burdens and risks. To ask a contractor to accept compensation for all of the costs he has actually incurred in connection with the terminated contract plus a profit on that portion of the contract with respect to which he has actually performed work or rendered services is not to ask too much of him. ${ }^{226}$ In fact this whole situation might well be regarded as one of the "circumstances" in the light of which the profit allowance is to be determined, thereby bringing the restriction on the contracting officer's discretion within the provision of paragraph (c) itself.

Paragraph (c) of the new standard form, as previously indicated, ${ }^{227}$ is entirely without restrictions, even as to the scope of the profit allowance. PR 324 has suspended in large measure the previous instructions in PR 'I5 relating to the old form and has indicated that new instructions will shortly be issued. In advance of the issuance of such instructions it is impossible to say how closely they will approach the rules laid down as to negotiations in connection with the old article.

In determining the amount of profit to be allowed on work done on the uncompleted portion of the contract a contracting officer in applying the old form is not restricted by any formula or fixed percentage or by any particular method of computing the allowance. ${ }^{228}$ Each case stands on its own; the contracting officer is to exercise his best judgment in deciding how to compute such profit allowance in

${ }^{228}$ See PR 15-56r.

${ }^{228}$ Quaere whether, in the event of termination of a large number of contracts at the cessation of all or a substantial part of hostilities, it could not be maintained that as a matter of law a contractor was entitled to no profit, even with respect to work performed in connection with the uncompleted portion of his contract. The basis for such a position would be that the contract had been necessitated by the war and would not have been made but for the war, and further that the partics must have contemplated that the war might end while the contract was in the process of being performed. That possibility having become an actuality the essential purpose of the contract would have been frustrated, so that the law would leave the parties where it found them or, at best, merely compensate the con. tractor for his costs in connection with the uncompleted portion of the contract. See Buffalo Union Furnace Co. v. U. S. Ship. Board, E. F. Corp., 29r F. 23 (x923); Russell Motor Car Co. v. U. S. 26r U. S. 514 (1923); 6 Williston, Contracts (2nd ed. 1936) 5472; Corbin's Anson, Contracts (5th ed. 1930) $463,466$.

${ }^{227}$ Supra 456.

${ }^{228}$ House Hearings 43; PR 15-449. 
each case, and in computing it. ${ }^{229}$ Certain criteria are suggested for his guidance, however, in the exercise of this very broad discretion. ${ }^{230}$ These include:

x. The total work required of the contractor and the extent to which it has been completed.

2. The relative difficulty of the work which has been done and of that which remains to be done.

3. The extent to which engineering work, production scheduling, technical supervision and other services requiring special schedule have been performed by the contractor.

4. The extent to which the contractor has arranged a program of subcontracting and its importance in the performance of the contract.

5. The extent of the services rendered in procuring raw materials, parts or subassemblies. ${ }^{231}$ Where this has merely been a process of purchasing standard materials and parts the profit to be allowed with respect to this aspect of the contractor's work should be relatively lower than on those aspects of his work which represent substantial contributions in the way of engineering, technical skill, management and supervision. ${ }^{232}$

6. The contractor's accounting data as to his costs of performance.

7. The contractor's data as to the extent of costs necessary to complete the. contract. $^{233}$

8. The profit which the contractor would be allowed upon an application of the formula provision contained in paragraph (d) of the standard termination article. Under this provision the profit is determined by estimating the contractor's total profit if the contract had been completed and multiplying it by the estimated percentage of completion of the uncompleted portion of the contract. Of course, in the case of the negotiation of a settlement, the contractor is not required to apply this formula, but to the extent that the formula represents a statement of the principles of an equitable determination of the profit allowance it can serve as a valuable guide. ${ }^{234}$

9. In the case of a termination of a contract at an early stage of the work thereunder there may be little data available with respect to the contractor's actual costs and probable rate of profit. Under these circumstances the contracting officer might consider the contractor's statement of estimated costs furnished at the time the contract was negotiated, ${ }^{235}$ the contractor's profits on other work and any available information with respect to the profits of similar contractors on similar work.

Io. Where the evidence indicates that the contractor would have sustained a loss if he had completed his contract this would be a factor for the contracting officer to weigh, along with all other factors. Where the contracting officer is

\footnotetext{
230 PR $15-449$.

330 Id.

${ }^{232} \mathrm{PR}$ 15-451.2.

234 PR $15-450$.
}

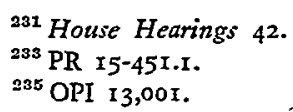


following the "Inventory Method" a contractor's indicated loss is automatically taken into account, since there will be no profit to be added to the costs with respect to the uncompleted portion of the contract. Where the "Total Cost Method" is being used the contracting officer is expressly instructed to adjust the amount deducted for payments for completed items to reflect the indicated loss. ${ }^{236}$

II. The negotiated settlement, however, is not to include those portions of the contract still uncompleted but with respect to which the Government has agreed to reimburse the contractor on a cost basis. Typical is the contract under which the contractor is to acquire, or produce and use, certain facilities, the cost of which is to be borne by the Government. Such costs are eliminated from consideration in negotiating the settlement and are determined on the basis of an audit. ${ }^{\mathbf{2 3 7}}$

Admittedly, these criteria are couched in general terms and seem to establish no fixed standards. But in this fact lies the keystone of the negotiated settlement; it represents the element which preserves the basic flexibility by enabling the contracting officer to engage in a process of "give and take"238 with the contractor and leaves him free to arrive at the fairest possible settlement in each situation. ${ }^{230}$

\section{Formula Settlement}

While experience to date indicates that the number of terminations which will be settled by formula is negligible, ${ }^{240}$ provision has been made in paragraph (d) of the standard forms of termination articles for those cases in which the con. tracting officer and the contractor will be unable to agree upon the amount to be paid to the contractor to compensate him for his costs and profit with respect to the uncompleted portion of the contract. This paragraph in the old form provides that if no negotiated settlement of this amount is arrived at within ninety days from the effective date of the termination notice, or within any agreed extension of this period, the contractor is to be compensated for his actual costs with respect to the

280 PR I5-452.2.

287 PR I5-42X.4.

${ }^{238}$ House Hearings 43.

${ }^{280} \mathrm{PR} \times 5-220(\mathrm{I})$ requires the establishment, for the assistance of each contracting officer engaged in the termination of contracts, of an advisory board to review each proposed settlement involving a payment of more than $\$ 5,000$ on the uncompleted portion of the contract. This review is to take place prior to the execution of any settlement agreement by the contracting officer. PR 15-220(3) requires a similar review in the office of the chief of the technical service concerned of every proposed settlement agreement or partial payment involving the payment of more than $\$ 1,000,000$. "It became apparent shortly after the publication of PR 15-220 that such mandatory centralized review of settlements would greatly delay terminations. Experience has shown that large termination settlements, must take place over a period of some weeks, on the basis of piecemeal approval of various separate steps and stages of the settlement, such as settlement of particular subcontracts, sales of inventory or portions of inventory, payments for particular portions of inventory, and similar steps. To require a Washington approval of a final settlement means that either (a) approval is given of a settlement which in large part has already taken place in sections, or (b) substantial delays occur while Washington approval of each step in the settlement is obtained. Accordingly, for the Ordnance Department and the Army Air Forces-those are, of course, two of the largest contracting branches-the provisions of PR 15-220 have been temporarily suspended while studies are being conducted in procurement offices. in various parts of the country in an attempt to work out revicw procedures which will best accomplish the dual objective of protecting the Government's interests and of handling a large volume of terminations effectively and rapidly." (Under Secretary of War Patterson, Senate Hearings 305.)

${ }^{240}$ See supra, note $7 \mathrm{r}$. 
uncompleted portion of the contract, for his actual costs in settling or discharging his obligations with respect to the uncompleted portion of the contract at amounts approved by the contracting officer, ${ }^{241}$ and for his profit with respect to the uncompleted portion of the contract computed by estimating the total profit if the contract had been completed and multiplying that estimate by the estimated percentage of completion of the uncompleted portion of the contract. Paragraph (d) of the new standard form, which has previously been discussed, ${ }^{242}$ differs chiefly in that it substitutes definite profit percentages for this method of computing profit on the basis of estimates, and requires the application of these percentages to cost figures determined in accordance with this new paragraph (d).

Because of this provision the formula settlement probably necessitates a considerably more detailed audit by the contracting officer's accounting personnel in order to determine such actual costs, and the submission to the General Accounting Office of the evidence upon which the settlement is based, ${ }^{243}$ although no further audit will be required with respect to the contractor's settlements of his obligations and commitments to his subcontractors which have previously been approved by the contracting officer, ${ }^{244}$ It is this necessity for an audit and the collection and submission of specific evidence which makes the negotiated settlement so much more preferable than the formula settlement, as previously indicated. 245 Similarly, any termination article which provides for the payment of "costs" with respect to the uncompleted portion of the contract and makes no provision for some form of negotiated settlement is less preferable than one which provides for the negotiation of a settlement. While the principles of cost determination set out in PR $I_{5}$ are not applicable to a settlement by formula under the old standard form, ${ }^{246}$ it is probable that to a large extent the cost definitions set forth therein ${ }^{247}$ will nevertheless be applied in determining allowable costs under a formula settlement, since those principles and definitions constitute a reasonable and workable standard for determining the cost items which should or should not be allowed as having been incurred with respect to the uncompleted portion of a contract. These principles are expressly made applicable to formula settlements under the new article, by paragraph $(h)$ thereof.

Clearly, any determination of "actual costs" or of "profit" for the purposes of a formula settlement is a determination of fact. ${ }^{248}$ Therefore, if a contracting officer and a contractor do not agree as to any portion or all of the contracting officer's determination of such actual costs the contractor has his recourse in the form of an appeal under the particular "Disputes" article ${ }^{249}$ set forth in the contract. The cost and profit as fixed in the foregoing manner represent the contractor's com-

${ }^{241}$ See supra 474 .

${ }^{342}$ Supra $456 \mathrm{ff}$.

244 See PR 15-325.2(2).

240 PR $15-42 \pi .2$.

${ }^{243}$ See supra 463 .

${ }^{245}$ See PR 15-40I; see supra 464 .

${ }^{247}$ See PR I5-48I-15-485.

${ }^{348}$ See U. S. v. Callahan-Walker Const. Co. 3I7 U. S. 56 (1942), holding that the determination of an "equitable adjustment" is a determination of fact.

${ }^{240}$ Sec PR 326. 
pensation with respect to the uncompleted portion of the contract, subject to such review as the General Accounting Office may make of the audit and other evidence furnished to support the contracting officer's finding as to the amount of such compensation. Since the compensation is based on a finding of actual costs and actual profit earned there is no doubt that this finding must be supported by evidence which will be regarded as adequate by the General Accounting Office. ${ }^{250}$

\section{Equitable Adjustments under "Changes" Articles}

Most Government contracts contain a "Changes" article which authorizes the Government to order changes in the drawings, or specifications, and sometimes in the rate or quantity of deliveries. ${ }^{251}$ That article generally provides, in effect, that where the nature of the change is such that it will increase or decrease the contractor's costs an "equitable adjustment" is to be made in the contract price. It would appear that many of the problems confronting a contracting officer in connection with the termination of a contract may also confront him in connection with a change in drawings, specifications, packing, delivery or quantities required under a contract. For example, there may frequently be problems involving the disposition of property not necessary for the performance of the contract as changed. Certainly there will be problems of determining the contractor's costs and of how he is to present such costs. Likewise, there may be problems of determining a proper allowance for profit on work in process which the change has made unnecessary. The very term "equitable adjustment" suggests negotiation between the contracting officer and the contractor with respect to the amount of the increase or decrease in the contract price necessitated by the change. While this situation is nowhere mentioned in PR $I_{5}$ or in TAM it is believed that, to the extent that the problems are similar, the principles set forth in PR I5 and TAM, particularly those relating to cost determinations and profit allowances, should be made expressly applicable to a determination of the equitable adjustment in connection with a change order. Whether or not this is done, however, it is probable that contracting officers and contractors confronted with a necessity for making such equitable adjustments will find many valuable procedures and guides in PR 15 and TAM which will assist them in making speedy, as well as "equitable," adjustments.

\section{Other Types of Contracts}

\section{Preliminary Contractual Instruments}

Various forms of preliminary contractual instruments have frequently been used to enable contractors to start work immediately on supplies required by the War Department, without waiting for the accumulation of the information necessary for the negotiation of a definitive contract. ${ }^{252}$ These forms have included the letter of intent, the letter purchase order, and the letter contract. All of these now have been superseded by the letter order in two different forms, one with no price

\footnotetext{
${ }^{250} \mathrm{Sec}$ supra 462.

${ }^{261}$ See PR 1301.2, PR 329-A. $\quad{ }^{252}$ See PR 303-A.
} 
stated $^{253}$ and one with a price stated..$^{254}$ The letter of intent commonly used stated that it was the intention of the Government to place a contract for a specified item, authorized the contractor immediately to purchase materials and equipment necessary for the manufacture of that item, up to a stated amount, and provided that if no contract was entered into prior to a specified date the Government would reimburse the contractor "for the costs incurred" by him. The letter purchase order actually placed an order for a specified item, but price, delivery schedules and the terms and conditions of the contract were left to further negotiation. Under it the contractor was authorized immediately to procure the necessary materials and equipment and begin the manufacture of the item. If the letter purchase order were terminated for any reason before a definitive contract was executed the Government bound itself to reimburse the contractor "for the costs incurred in the performance of this order." It also provided that "all applicable clauses required by . . . Procurement Regulations to be included in contracts for supplies of the kind" covered by the order were incorporated therein by reference. The letter contract was a similar instrument, except that it was actually a contract for a definite quantity at a definite price. It contained a provision for payment of "a sum equal to reimbursement for all costs incurred ... . in connection with the performance" of the contract in the event of termination, and also contained the foregoing provision with respect to the incorporation by reference of all clauses required by Procurement Regulations.

So far as termination is concerned, therefore, the letter of intent presents no problem, at least with respect to determining what procedure is to be followed. The agreement of the Government to reimburse the contractor for his "costs" again means reimbursement on the basis of an audit and specific evidence. The letter purchase order and the letter contract, however, present an interesting problem, because of the provision for incorporation by reasons of the applicable mandatory clauses. One of such clauses is the standard form of termination article. The express agreement in the letter purchase order and the letter contract to reimburse for "costs" with no mention of any profit is clearly inconsistent with paragraph (c) of the standard forms, providing for a negotiated settlement with respect to such costs, plus a profit on the uncompleted portion of the contract. Therefore, considerable doubt is cast on the incorporation of the termination article because of this specific language in the letter purchase order and the letter contract. While it might be said that even if this is so the remainder of the standard form is nevertheless incorporated by reference, there would be little practical value to this result without the provision for the negotiated settlement.

Since the letter of intent, letter purchase order and letter contract were superseded by the letter order form, this problem has been solved because this form contains a complete provision for termination ${ }^{255}$ based on a negotiated settlement, and permission has been granted. for the addition of this form of termination article

\footnotetext{
${ }^{253}$ PR 1307.

254 PR 1308.

${ }^{205}$ PR I307.6, I308.6.
} 
by supplemental agreement to existing letters of intent, letter purchase orders and letter contracts when any of such instruments is about to be terminated, or even after notice of termination has been served. ${ }^{256}$ The termination article contained in the new letter order form provides that upon termination of the letter order the Government and the contractor will attempt to negotiate a settlement "of the amount to be paid by reason of such termination." This settlement is to include "such allowance of profit ... with respect to the work done . . . as the contracting officer may find reasonable under all the circumstances."257 However, no allowance for profit is to be made where the letter order is terminated because of the inability of the Government and the contractor to agree upon a definitive contract to supersede the letter order. Provisions substantially similar in effect to those in the standard form of termination article with respect to the sale or retention by the contractor of property on hand, the vesting in the Government of title to all the property in the possession of the contractor after payment of the termination costs and the making of partial payments are also included.

The authority to include this termination article in existing letters of intent, letter purchase orders and letter contracts, however, expressly forbids the inclusion of the foregoing provision authorizing an allowance to a contractor of a profit on work done under the preliminary contractual instrument. ${ }^{258}$ Since it is the established War Department policy to have such preliminary contractual instruments superseded by definitive contracts as quickly as possible, ${ }^{250}$ it would appear that this express prohibition is designed to act as a strong inducement to contractors to enter into such definitive contracts at the earliest opportunity. It has that effect because the definitive contract will contain the standard form of termination article, under the terms of which the contractor does receive an allowance for profit on work done with respect to the uncompleted portion of the contract.

In general, policies and procedures applicable to terminations of definitive contracts containing the standard form of termination article are to be applied to terminations of preliminary contractual instruments subject, of course, to such modifications as may be necessary because of any differences between a preliminary contractual instrument and a definitive contract. ${ }^{200}$ Therefore, to a very large extent, all of what has been said heretofore concerning the termination of definitive contract applies to the termination of such preliminary contractual instruments. Clearly this is desirable; it results in uniformity of procedure, certainty on the part of contractors and contracting officers as to what the procedure will be and gives a contractor under a terminated preliminary contractual instrument the benefits of the

${ }^{250} \mathrm{PR}$ 15-107.2(2), 15-701.2.

IEt This provision for profit may be included only where the conditions set forth in PR 303-A.I are met. These conditions are (I) that the Government is unable, in the particular case, to furnish full specifications or necessary information so that the letter order will necessarily remain in effect for a considerable period of time, or (2) that the contractor is willing to quote a reasonable fixed price but the Government, for its own convenience, is unwilling immediately to negotiate a definite contract. ${ }^{258}$ PR 15-701.2.

${ }^{250}$ PR 303-A. ${ }^{200}$ PR 15-702. 
speed and equity which the contractor under a definitive contract gains under the foregoing termination policies and procedures.

While it has thus far been omitted from the discussion, the Notice of Award ${ }^{261}$ is also a preliminary contractual instrument in a sense, because it is a binding contractual instrument based on an offer by a contractor which is accepted by a contracting officer, but which will eventually be superseded by a definitive contract. However, the Notice of Award contains no provision for termination. For this reason it may be terminated and settled on the same basis as a definitive contract which contains no termination article. ${ }^{262}$ This gives the holder of a Notice of Award some advantage over a holder of a letter of intent, letter purchase order or letter contract in that on termination he might receive an allowance for profit with respect to work done. However, this distinction is probably correct since the notice of award represents a contract with respect to which all important provisions have been agreed upon, while the other instruments represent situations in which further negotiations are still necessary to arrive at a substantial meeting of the minds of the parties.

\section{Lump Sum Construction Contracts}

A construction contract, by its very nature, differs from a supply contract in that the construction contract typically is a contract for one complete item, i.e., the building to be constructed, while the supply contract is a contract for a number of items each of which has its separate contract price. Therefore, on termination a supply contract may be divided into a completed and uncompleted portion, while a construction contract cannot; on termination there is only an uncompleted building.

Except for such variations as might be necessitated by this difference in the essential nature of the two types of contracts the principles and procedures applicable to their termination would be expected to be the same. This, as a matter of fact,

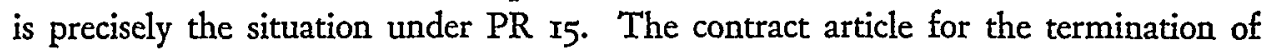
lump sum construction contracts ${ }^{263}$ is similar to the old form of termination article except that under paragraph (c) the negotiated settlement is applicable to all the work covered by the contract and not merely to the uncompleted portion of the contract. On the basis of this article all of the procedures in PR I5 with respect to lump sum supply contracts are applicable to lump sum construction contracts, subject to such modifications as are required by the fact that the article is not restricted to the uncompleted portion of the contract. Thus the form of notice of termination is the same except that it is not limited to the uncompleted portion of the contract. ${ }^{264}$ The same is also true with respect to the formula provisions of the construction termination article, ${ }^{265}$ the settlements with subcontractors, ${ }^{266}$

\footnotetext{
301 OPI I3,002.

${ }^{203} \mathrm{PR} 324 . \mathrm{T}$.

${ }^{205} \mathrm{PR} 324 . \mathrm{I}$, par. (d) (3).
202 PR I5-702. See PR I5-3II and supra 467.
${ }^{206} \mathrm{PR}$ I5-9I2.I, notes $I$ and 3 .

${ }^{200}$ PR $15-325.2$, notes $I$ and 2 .
} 
the contractor's cost statement and proposal for settlement, ${ }^{267}$ the making of partial payments, ${ }^{268}$ and the form of the final settlement agreement. ${ }^{208}$

\section{Cost-Plus-a-Fixed-Fee Contracts}

The tęrmination of a cost-plus-a-fixed-fee contract presents its own peculiar problems as well as many of the problems encountered in the termination of a lump sum contract. These special problems arise out of the special nature of the costplus-a-fixed-fee contract, a contract under which the contractor is to receive all of his actual costs as defined by the contract itself, plus a fixed fee instead of a profit, a fixed fee which is smaller than the profit on a lump sum contract because of the lesser risks borne by a cost-plus-a-fixed-fee contractor. Typical of such problems are the determination and reimbursement to the contractor of his actual costs both before and after service of the termination notice, adjustment of the contractor's fixed fee, disposition of property and settlement of terminated subcontracts, both lump sum and cost-plus-a-fixed-fee.

The cost-plus-a-fixed-fee termination articles heretofore in use have generally followed substantially the forms set out in PR 15-903 and PR 15-905. With respect to termination for the convenience of the Government these articles provide that such termination may be ordered at any time by a written notice from the contracting officer to the contractor, setting forth the time and manner of the termination. Unless otherwise directed the contractor must immediately discontinue all work and the placing of orders, and must cancel promptly all existing orders and subcontracts in so far as they are chargeable to the contract. Thereupon the Government assumes and becomes liable for all obligations, commitments and claims previously incurred by the contractor in connection with the work to the extent that they are reimbursable under the terms of the contract. ${ }^{270}$ Reimbursement of the contractor's costs prior to termination is to be completed in accordance with the cost provisions of the contract; he is also reimbursed for post-termination expenses incurred with the approval of the contracting officer. With respect to fixed fees, PR I5-903 (the Ordnance form) provides that the contractor is to be paid all those fixed fees which have "accrued" at the date of termination; PR I5-905 (the Army Air Forces Form) provides that the contractor is to be "paid a percentage of the fee . . . equivalent to the percentage of completion of the contract."

Obviously many of the termination procedures applicable to lump sum contracts will be applicable to cost-plus-a-fixed-fee contracts containing such an article. ${ }^{271}$ Thus, the preliminary steps prior to service of a notice of termination, ${ }^{272}$ such as consideration of the factors which will determine whether a particular cost-plusa-fixed-fee contract is to be terminated, authorization from the chief of the technical

207 PR 15-400, notes I and 2.

${ }^{208} \mathrm{PR}$ 15-502, note $\mathrm{x}$. ${ }^{200}$ PR I5-932.

${ }^{270}$ As a practical matter, however, many cost-plus-a-fixed-fee contractors regard this as only a secondary obligation and are actually settling these items themselves wherever possible.

${ }^{272}$ See PR 15-65I.I.

${ }^{272}$ Seq supra 467. 
service for the termination, the possibility of avoiding termination charges, the scope of the proposed termination, the preliminary conference with the contractor either prior to or immediately after service of the termination notice in order to acquaint him with his responsibilities and arrange a program for the termination of subcontracts, the disposition of property and the receipt from subcontractors of their inventories and proposals for settlement, are in many respects very similar, except that the contractor does not prepare any proposal for settlements, since he is reimbursed on an actual cost basis. The form of the termination notice ${ }^{273}$ is similar to the notice used in the case of the termination of a lump sum contract ${ }^{274}$ except that there is no request for the contractor to furnish a proposal for settlement.

However, there are also certain necessary differences in procedure. The contractor's own costs, both prior to termination and incurred in connection with the termination, are presented by him for reimbursement in accordance with the applicable cost and reimbursement provisions of the particular contract and, except for the claims of subcontractors which the contractor settles himself, ${ }^{275}$ are then audited by the same personnel and pursuant to the same procedures as have been utilized and applied in connection with the previous reimbursement vouchers submitted by the contractor. This creates no special burden since such audits were contemplated when the contract was originally entered into and the necessary machinery for such audits exists for each cost-plus-a-fixed-fee contract.

With respect to the adjustment of the fixed fee on termination, PR 15-651.9 says merely that it shall be made "in accordance with the terms of the terminated contract." As indicated above the Ordnance and Air Forces ${ }^{276}$ forms have different provisions with respect to this adjustment. The Ordnance form, which provides for the payment of "accrued" fixed fees raises the problem of whether the contractor is to be paid any fee on work in process at the time of termination. Since it can readily be argued that the word "accrued" includes fees partially earned in processing such uncompleted work, and since this interpretation will do substantial justice to the contractor, it would appear that this interpretation should be adopted when the problem actually arises. Especially is this so in view of the fact that the Air Forces form raises no such problem, but by providing that the contractor is to receive a percentage of the fee equivalent to the percentage of completion of the contract it clearly authorizes payment of a pro tanto portion of the fixed fee on work in process at the time of termination. Certainly there is no basis for any distinction between Ordnance contractors and Air Forces contractors on this matter.

Disposition of property in the possession of a prime contractor or subcontractor under a terminated cost-plus-a-fixed-fee contract also presents some differences from

\footnotetext{
278 PR I5-9I4.I.

274 See supra 468.

${ }^{275}$ Pursuant to $\mathrm{PR} 15-65 \mathrm{r} .3$ (2) these are treated in the same manner as subcontracts under a lump sum contract.

${ }^{270}$ These two services have by far. the greatest majority of War Department cost-plus-a-fixed-fee contracts.
} 
the disposition of property under a terminated lump sum contract. ${ }^{277}$ Cost-plus-afixed-fee contracts generally provide that title to property acquired in connection with the performance of such contracts passes to the Government on arrival at the site of the work or at an approved storage site. Consequently such property must be disposed of in accordance with the regulations applicable to the disposition of Government property. ${ }^{278}$ These regulations authorize the making of negotiated sales of such property, but such sales may be made only to war contractors or their employees or suppliers, and must be made by Government contracting officers. Also applicable is the statute requiring that the proceeds of such sales be forwarded to the Treasury as miscellaneous receipts, ${ }^{279}$ so that they may not be applied against the contract. However, in May I 943 the Judge Advocate General ruled ${ }^{280}$ that a provision $^{281}$ might properly be inserted in existing cost-plus-a-fixed-fee contracts under the terms of which Government-owned property in the possession of the cost-plus-a-fixed-fee contractor might be disposed of by the contractor at the direction of, or with the approval of, the contracting officer. Since then this provision has been incorporated in numerous cost-plus-a-fixed-fee contracts. Because it authorizes disposition of property by the contractor himself, subject only to the prior approval or subsequent ratification of the contracting officer, and because the proceeds of such disposition may be applied in reduction of any payments to be made by the Government to the contractor under the contract, the use of this provision presents many advantages over disposing of such property directly by the Government, both from the point of view of flexibility in the manner of disposition and applicability of the proceeds to the particular contract. Property in the possession of a subcontractor under a terminated cost-plus-a-fixed-fee contract is to be disposed of in accordance with the foregoing if title to such property has passed to the Government. ${ }^{282}$ If title to such property has not passed to the Government disposition is to be made by the same method as is applicable to property in the possession of a subcontractor under a terminated lump sum contract. ${ }^{283}$ Property which has become affixed to Government real estate is to be disposed of in accordance with the statutes applicable to Government real estate ${ }^{284}$ and with any pro-

$2 \pi 7$ See supra $47 \mathrm{r}$.

${ }^{270}$ rg StAT. 249 (I877), 3 I U. S. C. r940 ed. $\$ 487$.

${ }^{278}$ See PR 7, especially Section II.

${ }^{281} \mathrm{PR} 363$, which reads as follows:

${ }^{280}$ SPJGC I943/6630, May I4, 1943.

"It is recognized that property (including without limitation machine tool and processing equip. ment, manufacturing aids, raw, manufactured, scrap and waste materials), title to which is or may hereafter become vested in the Government, will be used by or will be in the care, custody or possession of the contractor in connection with the performance of this contract. With the approval in writing of the contracting officer (whether such approval is given prior to or after the giving of a notice of the termination of this contract for the convenience of the Government), the contractor may transfer or otherwise dispose of such Government-owned property to such parties and upon such terms and conditions as the contracting officer may approved or ratify, or, with like approval by the contracting officer, the contractor may itself acquire title to such property or any of it at a pricc mutually agrecable. The proceeds of any such transfer or disposition or the agreed price of any property, title to which is so acquired by the contractor, shall be applied in reduction of any payments to be made by the Government to the contractor under this contract, or shall otherwise be paid in such manner as the contracting officer may direct."

${ }^{282} \mathrm{PR}$ 15-65r.6(2).

${ }^{284}$ E.g. 43 U. S. C. 1940 ed. ch. 16.

${ }^{283}$ PR I5-651.6(2), (3). See stipra 472. 
visions of the terminated contract as to such disposition, including options to the contractor to purchase. ${ }^{285}$

The procedure applicable to the termination and settlement of subcontracts under a terminated cost-plus-a-fixed-fee prime contract represents a combination of procedures peculiar to the termination of cost-plus-a-fixed-fee contracts and of procedures heretofore discussed with respect to the termination of lump sum contracts. So far as possible the latter procedures, built around the negotiated settlement, are made applicable to lump sum subcontracts. ${ }^{286}$ Thus such a subcontractor is to furnish an inventory and a proposal for a negotiated settlement. ${ }^{287}$ Thereafter a settlement is to be negotiated with him either by the Government or the prime contractor, depending on the form of the termination article in the terminated cost-plus-a-fixed-fee contract. In most cost-plus-a-fixed-fee contracts entered into heretofore this article provides that on termination the Government "shall assume and become liable for all obligations, commitments and claims" incurred by the contractor in connection with the work..$^{288}$ Under such a provision the contractor's obligation is only to secure an inventory and proposal for settlement from each subcontractor and furnish it to the contracting officer. Thereafter it is the contracting officer's responsibility to negotiate a settlement with the subcontractor. ${ }^{289}$ Where the contracting officer settles with subcontractors under cost-plus-a-fixed-fee contracts, settlements are to be made in accordance with the provisions of PR I5 relating to the settlement of subcontracts under lump sum prime contracts, in so far as applicable. ${ }^{200}$

Obviously such a procedure has its disadvantages from the point of view of the most effective method of settling such subcontracts. The prime contractor, as the one who has dealt with the subcontractor, is in the best position to pass on his statement of charges and to negotiate a settlement with him. Many cost-plusa-fixed-fee prime contractors, recognizing the merits of this approach, are actually settling with their subcontractors themselves. In order to encourage and spread this practice, numerous existing cost-plus-a-fixed-fee contracts have been amended to include a new termination article, the principal innovation of which is a provision that settlements with respect to terminated lump sum subcontracts are to be made by the prime cost-plus-a-fixed-fee contractor by negotiation with each subcontractor. Each such settlement is expressly made subject to the approval of the contracting officer. Such settlements are to be negotiated in accordance with the regulations applicable to the settlement of lump sum subcontracts under lump sum prime contracts, in so far as applicable. ${ }^{201}$ Thus the most effective method of settling terminated lump sum contracts is made available for use in all cost-plus-a-fixed-fee prime contracts, a step which the War Department encourages as a matter of gen-

${ }^{280}$ PR $15.651 .6(4)$.

${ }^{280} \mathrm{PR}$ 16-65r.3(2). Pursuant to PR $15-651.5$ cost-plus-a-fixed-fee subcontracts âre to be settled on the basis of an audit and reimbursement in accordance with their terms.

${ }^{287} \mathrm{PR}$ 15-651.2.

${ }^{288} \mathrm{PR}$ I5-903(3) (a), 15-905(2) (a). $\quad{ }^{289} \mathrm{PR}$ 15-651.3(1).

${ }^{200} \mathrm{PR} 15-651.3(2)$.

391 Sce supra $473 \mathrm{ff}$. 
eral policy. ${ }^{292}$ The settlement of terminated lump sum subcontracts by negotiation between the prime cost-plus-a-fixed-fee contractor and the subcontractor raises the question of the extent of documentation which will be required to support reimbursement to the prime contractor of the amount paid by him, with the approval of the contracting officer, to the lump sum subcontractor pursuant to such negotiation. Apparently such amounts will be reimbursed to the prime contractor without being questioned by the General Accounting Office. Thus, in a decision dated June $19,1943,{ }^{293}$ the Comptroller General stated:

"Since the latter sum ... represents the cancellation charge duly agreed upon by the (subcontractor) and prime contractor, apparently without concealment, misrepresentation or fraud, it seems clear that reimbursement of the same under the prime contract cannot be held to be objectionable as a matter of law."204

During the process of finally determining the amount due on a terminated costplus-a-fixed-fee contract, partial payments based on approved reimbursement vouchers or fixed fee vouchers may be authorized by the contracting officer. ${ }^{205}$ PR $15-655$ states that when the final determination has been made of the costs to be reimbursed and the portion of the fixed fee to be paid a final settlement agreement is to be entered into concurrently with the final payment, as a supplement to the terminated contract. This agreement is to state the amount of such final payment, the terms of any adjustment of the fixed fee, that all Government property theretofore undisposed of has been delivered to the Government (such property is to be listed or a list incorporated by reference), will contain mutual releases by the contractor and the Government and will state in detail any exceptions to said release.200 However, since the execution of this agreement completely closes out the contract, costplus-a-fixd-fee contractors prefer not to execute such an agreement, principally because they do not know what action the General Accounting Office will take on reimbursement vouchers still to be reviewed by that office. There can be no real objection to this position, so long as the contractor agrees in some definitive form that no further costs will be submitted for reimbursement and that the amount of the fixed fee to be paid has been finally adjusted.

\section{Terminations and the Congress}

No discussion of the War Department's termination procedures would be complete, nor could those procedures be fairly and properly evaluated, without some consideration of the exhaustive scrutiny to which they have recently been subjected before the Congress. That scrutiny was largely in the form of hearings lasting almost two full months before the full House Military Affairs Committee and a

${ }^{202}$ PR $15-651.4(2)$.

${ }^{293}$ MS B-34255, June 19, 1943.

294 Cf. the statement of the Comptroller General, infra 504, to the effect that there is no legal objection to the negotiated settlement of terminated lump sum contracts.

${ }^{205} \mathrm{PR}$ 15-654.

200 The form of this final settlement agreement is set out in PR $15-933$. 
subcommittee of the Senate Military Affairs Committee; ${ }^{297}$ among those testifying were the Under Secretary of War, the Under Secretary of the Navy, the Comptroller General, the Attorney General, the Secretary of Commerce, the Chairman of the War Production Board, the General Counsel of the Treasury Department, the Commissioner of Labor Statistics, the Chairman of the Smaller War Plants Corporation, the Chairman of the Maritime Commission, the President of the American Federation of Labor, ${ }^{298}$ and numerous representatives of the automotive, aircraft, shipbuilding and other industries directly connected with the war procurement program. The witnesses were unanimous as to the need for speedy, fair and final termination settlements. The hearings therefore devolved into a discussion of whether the negotiated settlement as previously described, was the best means to that end, with Under Secretary of War Robert P. Patterson as its principal protagonist and only the Comptroller General objecting to its use for that purpose. $^{290}$

These extended hearings ${ }^{300}$ were precipitated by a letter ${ }^{301}$ which the Comptroller General, on September 20, I943, wrote to Senator James E. Murray, in response to the Senator's request for comments on S. 1268, a bill dealing with interim financing of terminations, ${ }^{302}$ which was then being considered. After commenting on this bill the Comptroller General discussed the War Department's negotiated settlement procedure as an example of "a growing tendency on the part of some administrative departments and agencies, by means of regulations or contract provisions, to vest in contracting officers or their representatives final authority to adjust and settle claims against the United States in derogation of the authority and jurisdiction vested in the General Accounting Office by the Budget and Accounting Act of I92I, 2I U. S. C. 4I." He further stated that in his opinion the negotiated settlement procedure, under which contracting officers would be authorized to conclude final settlements, would not adequately protect the interests of the United States, and concluded with a recommendation "that specific provision be made in any legislation which may be enacted to insure that the General Accounting Office may make a proper audit and review of the claims asserted in connection with the settlement of the Government's obligations under terminated contracts," and presented a draft of such legislation.

'On October 15, I943 Under Secretary Patterson appeared before the full House Military Affairs Committee to explain the necessity for the negotiated settlement

\footnotetext{
${ }^{207}$ Hearings have also been held by the Senate's Special Committee on Post-war Economic Policy and Planning under Senator Walter F. George, and by the Truman Committee.

${ }^{208} \mathrm{He}$ appeared before the Truman Committee; see infra 506.

200 Though not represented at any of the hearings, the Board of Governors of the Federal Reserve System, on November 17, 1943, issued a statement in which they briefly reviewed the whole problem and took an unequivocal position that terminated contracts must be "settled promptly and finally by negotiated agreements between the contractor and the procuring agency" and that "settlements so negotiated should be final and not subject to review by any other agency except for fraud."

${ }^{800}$ Much of the testimony before the Senate Committee was similar to that before the House Committee.

${ }^{\mathrm{a} 02}$ MS B-35374, Sept. 20, 1943.

${ }^{302}$ See Cleveland, supra, note 31 .
} 
and to recommend the adoption of legislation specifically authorizing the use of that procedure. ${ }^{303} \mathrm{He}$ pointed out that the termination problem was a present problem, the War Department as of August 3I, I943, having completely or partially terminated 8,520 contracts with a total of uncompleted work of $\$ 5,800,000,000,304$ which was almost $\$ 2,000,000,000$ more than the total uncompleted portion of all contracts terminated at the end of the first World War. Such a volume of terminations inevitably affected current production, he said, and also gave rise to fear on the part of the contractors as to how such termination would be settled. So long as this was uncetain they would be reluctant to expand operations or make extensive future commitments. So, for the sake of current production he declared it to be necessary to assure both business and labor that workable and definite plans existed for a prompt conversion to civilian production. He pointed out the complexity of the problem by stating that the War Department alone had over ro0,000 prime contracts of sufficient size or complications to present real cancellation problems. These, in turn, involved at least one million relatively large subcontracts. ${ }^{305}$

To meet this problem the War Department had developed a program which it regarded as adequate to meet the present and the conceivable future task. This program, he said, has two objectives:

I. "The fair and final adjustment of canceled contracts at the earliest moment consistent with adequate protection of the Government interest."

2. "The provision of adequate means for interim financing of contractors whose contracts have been terminated."306

The attainment of these objectives he characterized as being "of crucial importance both to our current production of munitions and to the future economic and political stability of the country." 307

He then discussed each of the following principles, adoption of which he declared was essential if the objective of fair, prompt and final settlement was to be attained:

I. Termination adjustments must be effected by negotiated agreements.

2. The negotiations must be final and not subject to reopening by any inde. pendent agency, except for fraud.

3. The negotiations must be conducted by the procurement agencies. ${ }^{308}$

Negotiation was necessary because costs on a terminated contract were not susceptible of exact determination by an examination of the contractor's books, but required the composition of honest differences of opinion and the exercise of business judgment, based on adequate data. Agreements made in this fashion had to be final, except for fraud, because any review would involve the exercise of new judg-

${ }^{302}$ House Hearings 153. Such legislation was then thought advisable because the Comptroller General's letter appeared to question the legality of the negotiated settlement. See Senate Hearings 31\%. But see infra 504 for the Comptroller General's statement that he did not raise any question as to its legality.

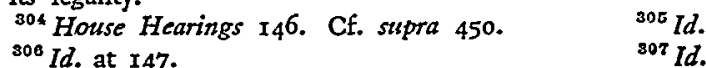

${ }^{306}$ Id. at 147 .

${ }^{308} I d$. at 147 , 148 . See $i d$. at $148-152$ for a detailed discussion. 
ment by the reviewer and would amount to a new negotiation, rendering the first useless and preventing any action on the basis of the agreements reached in the first negotiation, thereby delaying the whole process. The negotiations had to be conducted by the procurement agencies because the problems involved were intimately related to procurement and could not well be separated without interfering with procurement. Frequently a contract was terminated to make the contractor available for other work, so that the treatment of the termination would affect the negotiation of the new contract. In many cases materials and work in process could be used on other contracts; only the procurement agencies involved could know that. This did not mean that each agency should go its own way in establishing its termination policies and procedures. Basic uniformity was essential; for that reason the War Department urged the creation of an interdepartmental committee with authority to adopt uniform provisions and basic policies and procedures. $^{309}$

Judge Patterson then proceeded to explain in some detail how the War Department's procedures for negotiating termination settlements adequately protected the Government's interests and did not authorize contracting officers to make such settlements on the basis of unverified cost statements from the contractors. He criticized the notion that the negotiations were conducted by one individual, pointing out that a complete organization worked on each case. His description of the procedures and safeguards was brief but complete, and designed to dispel any doubt as to their adequacy. He said:

"The contractor is first required to submit a detailed inventory of work in process and materials and a sworn proposal for settlement of the amount due therefor, supported by adequate cost schedules. The inventories of property are studied by competent Government engineering, salvage, and other technical personnel. Then the property is either disposed of or retained by the contractor on terms approved by the Government, or it is transferred to the Government. The proceeds of any sale are credited or paid to the Government. The cost records of the contractor and his proposal for settlement are checked in substantially all cases by Government accounting personnel. This check ranges from an office review to a detailed audit, depending on the circumstances of each case. In practice the scope of the accounting and audit to be done in each case is determined by trained accounting personnel. To economize in the use of personnel and because of the necessity for speed, the principles of selective accounting analysis (or spot check) are employed wherever possible; the primary object is to test the reliability, general fairness, and reasonableness of the contractor's figures. In cases of apparent fraud or attempts to overreach the Government, intensive audit procedures are employed. In the check by the Government full use is required to be made of any information about the contractor's accounting methods and business, obtained in statutory renegotiation proceedings and in the Government's files.

"By these methods, the negotiators for the Government have available reliable accounting data and other information on which to reach a fair settlement with the contractor. These negotiators are assisted at all stages by Government accounting, engineering, legal, fiscal, and technical personnel, all of whom participate in the negotiations and are consulted where their assistance may be helpful. The settlements eventually reached thus

${ }^{300}$ See sapra $45 x$. 
reflect the deliberations and advice of many different Government representatives, each a specialist in some particular field. In addition, the conduct of the negotiations and the final agreement are under the supervision of special agencies created for this purpose. These include a fiscal representative, under a duty to report to the commanding officer whenever, in his opinion, settlements are being improperly handled or considered. For each termination settlement appropriate records are kept of all important steps in the negotiations and all important actions by the contracting officer in order to indicate the essential data on which the negotiations were based.

"These various measures are carefully designed to provide all necessary protection for the interests of the Government."310

On October 18, r943, Comptroller General Lindsay Warren appeared before the same committee. His testimony removed any doubts which had previously existed as to his position on the legality of the negotiated settlement procedure. He did not "contend that . . . they do not have the right to terminate contracts. I say that they do have the right to terminate contracts under the War Powers Act, to issue regulations and to make final settlements."311 This therefore framed the issue solely as an issue as to the desirability of that procedure. On that issue the Comptroller General made himself clear at the outset by stating that "the settlement of . . . contracts are being made now and planned for the future under orders issued by the War Department without any adequate protection to the public interest."312 His characterization of the safeguards provided by the negotiated settlement was completely at odds with the foregoing description by Under Secretary Patterson:

"And what are these regulations? Well, they place conclusive and final power in the contracting officer. Even the auditors of the War Department who are instructed as to their duties and procedures in the regulations are cautioned to be constantly reminded that their findings are only for the information of the contracting officer and that he is not bound by anything they may produce or recommend, but have a free hand. The spot check it authorizes in some instances is an insult to proper audit of a matter of this magnitude. They require no verification of the contractor's statement of cost, unless specifically directed to do so by the contracting officer, which probably would only be done in exceptional cases. Under the authority granted to contracting officers by the regulations, it would be possible for them to negotiate a settlement with the contractor without any audit or verification of the items asserted by the contractor as constituting his claim. They provide that in such negotiations no documentary evidence such as is in force on cost-plus contracts shall be submitted to the disbursing officer and that such determination shall neither be reviewed by the disbursing officer nor the General Accounting Office."313

Indeed he specifically questioned the adequacy of the procedure described by the Under Secretary because there was "nothing in the regulations of the War

${ }^{310}$ House Hearings 151,152 . See $i d$. at 39 . for a good description of a contracting officer as "a large corporate entity."

${ }^{311} I d$. at 220. See Senate Hearings 343, where Attorney General Francis Biddle said that "under the law the contracting officers already had the power to negotiate and terminate contracts, irrespective of the (First) War Powers Act, and that there is nothing in that statute which changed that legal power of the contracting officers."

${ }^{312}$ Id. at 189 , 190.

s1s Id. at I9I. 
Department which have been brought to my attention to date in any way requiring the contracting officer to rely upon the assistance, information and advice thus to be available to him and nothing therefrom which would restrict his freedom of action in negotiating termination settlements finally and conclusively."314

To substantiate his position that contracting officers should not have conclusive and final authority over termination settlements, the Comptroller General produced 270 cases "pulled at random" to illustrate the sort of items War Department contracting officers had been allowing on cost-plus-a-fixed-fee contracts, which had been suspended or disallowed by his office.315 Instead of vesting final authority in contracting officers he urged a review of termination settlements by an independent agency, such as the General Accounting Office which is an agency of Congress, and which he heads. He recognized the necessity for some partial payments to a contractor while this review was in process, and therefore proposed a payment not in excess of $75 \%$ of the amount preliminarily determined by the procurement agency to be due, this payment to be subject to the final determination of the General Accounting Office. ${ }^{316}$

Under Secretary Patterson's reply to the Comptroller General's 270 cases took the form of a statistical analysis of the extent of actual disallowances by the General Accounting Office on War Department vouchers. He cited three facts to support his answers:

r. The General Accounting Office has made no exceptions to 99.5 percent of the vouchers submitted to it by the War Department for audit in the 4 months ending with August, r943. Furthermore, the majority of suspensions by the General Accounting Office are merely temporary, until further supporting documents are submitted, and do not involve any real questions as to the propriety of the payment.

2. Aside from items called to its attention by the War Department, disallowances by the General Accounting Office have currently totaled less than ro cents per $\$ 1,000$ of expenditures under War Department contracts.

3. Ninety percent of the money amount of the cases submitted to the Committee by the Comptroller General represents either items subsequently allowed by him,

sid Id. at I92. But see Senate Hearings 299 ff. and PR 15-304 through 15-306, 15-312, 15-32x, 15322, 15-400 through 15-496, 15-532 through 15-534.

${ }^{315}$ See House Hearings 253 for Under Secretary Patterson's letter of September 25, I943 to the Comptroller General, in which he discussed the cases which hold that where a contract provides for the decision of specified matters by a designated official, the decision of that official is final and conclusive on the parties, in the absence of fraud or bad faith, and questioned the authority of the General Accounting Office to substitute its judgment for that of the contracting officer who, by the terms of the cost-plus-a-fixed-fee contracts involved, was authorized to determine which items of cost were to be reimbursable.

${ }^{310}$ House Hearings 189, 610; Senate Hearings 211. Representative John M. Costello pointed out (House Hearings 235), however, that such a partial payment would be of litule value to a contractor if the General Accounting Office could subsequently make a determination which might require him to return some of it. 
or items brought to light by the War Department itself in its regular audit, which were in the process of correction before they came to his attention. ${ }^{\mathbf{3 1 7}}$

Then he proceeded to reiterate his insistence on the impracticability of an independent review of termination settlements, which he said would not be "ultimately in the public interest" because the inherent delays would both deter war contractors from assuming new obligations and would greatly retard the transition to peacetime production.

The foregoing discussion illustrates sufficiently the divergent views of the War Department and the Comptroller General concerning the method to be followed in arriving at final termination settlements. The committees also heard about twenty witnesses from various segments of industry, all of whom testified in favor of the negotiation of final termination settlements by the war procurement agencies.

The War Department's position in these hearings was also the position taken by the Navy Department ${ }^{318}$ and by the Maritime Commission. ${ }^{319}$ It was also supported by the Attorney General, ${ }^{320}$ the General Counsel of the Treasury Department $^{321}$ and the Commissioner of Labor Statistics. ${ }^{322}$ William Green, President of the American Federation of Labor, in the course of testimony before the Truman Committee, made the following approving comment on the negotiated settlement:

"For the termination of war contracts we recommend legislation ... . to provide authority to the procurement agencies to negotiate final settlement with contractors on the basis of policies and procedures developed by (a policy) council (composed of representatives of management, labor, farmers, the Senate and the House of Represntatives)."323

On this same issue Senator James E. Murray, Chairman of the Subcommittee of the Senate Military Affairs Committee, before whom much of the foregoing testimony was given, and who is vitally interested in the whole problem of termination settlements, said:

"Of course, it would seem to me reasonable that the agency that initiated the contract--had been in contact with the work throughout-would be in a much better position to discover whether or not anything went wrong than an entirely new agency that came in after the contract had been terminated."324

The whole problem therefore resolves itself into a determination of whether the negotiated settlement procedure provides adequate protection for the Government. On this, no more can be said than was said by Judge Patterson before the Senate Subcommittee. After discussing in considerable detail the provisions in PR ${ }_{5} 5$ which

${ }^{812} I d$. at $25 \mathrm{x}, 252$. These were subsequently criticized by the Comptroller General (id. at 512, . 514) as "assertions." But see id. at 623,626 .

${ }^{328}$ Senate Hearings $266 \mathrm{ff}$.

${ }^{319}$ Id. at 177 .

${ }^{322}$ Id. at 142,147 .

${ }^{320} \mathrm{Id}$. at $343 \mathrm{ff}$.

${ }^{223}$ Bureau of National Affairs, Washington Daily Reporter System, No. 244, Dcc. 3, 1943, A-20. No other representatives of labor have taken a public position on this question.

${ }^{324}$ Senate Hearings 312. 
constitute such protection, ${ }^{325}$ and which set forth the War Department regulations concerning group action in termination matters; conferences with and instructions to the contractor; accounting and auditing of cost statements, sworn to by the contractor; preservation of accounting reports; review of subcontractors' claims; application of principles of cost determination; utilization of all persons concerned in negotiations with the contractor; and the negotiation of the termination settlement, he summed up the situation as follows:

"When all these things have been done, and not until then, is a supplementary agreement terminating the contract signed with the contractor. And during the course of the negotiations it can be seen that the Government's interest has been fully protected in at least six ways. These are-

"I. The Government office most familiar with the contract has arrived at a decision as to the amount due.

"2. This decision has been reached not by one man but by a team made up of specialized and trained personnel. ...

" 3 . The decision was arrived at under regulations which require the development of adequate information.

"4. The decision was arrived at under regulations which provide proper and extensive standards for the exercise of judgment.

"5. The entire determination is carried on under the supervision of a responsible, experienced, ranking officer.

- "6. Before it is finally signed the agreement is carefully reviewed.

"If there are other safeguards which the committee might suggest, we shall be pleased to have such suggestions.

"You may have been led to believe that there was no adequate protection for the Government in the War Department's practice of contract terminations, yet I have just given you a brief statement of what actually takes place in our termination activities. as they are carried on today under the provisions of PR 15 .

"Mr. Chairman, under such regulations and procedures as these, the War Department is not paying out money for things that are not there.

"In view of the care with which we are checking all claims on termination, it is very difficult to see where the addition of another check by a different group of accountants from the General Accounting Office would add to the protection of the Government, unless this addition is based on the assumption that one group of Government accountants is more honest than another-an assumption that I have not heard offered."326

Recent developments indicate that the Congress will adopt the position of the War Department that termination settlements should be arrived at by negotiations. conducted by the procurement agencies, and that such settlements should be final and conclusive except for fraud. Thus, the House Military Affairs Committee, before whom substantially all of the foregoing testimony was given, announced on February 3, 1944 that it had voted by a margin of 13 to 7 for this conclusion. ${ }^{32 \pi}$ And on February II, I944 Senator Murray, for himself and Senator George, Chairman of the Senate Special Committee on Post-War Economic Policy and Planning,

\footnotetext{
${ }^{320}$ PR 15-304 through 15-306, 15-312, 15-321, 15-322, 15-400 through 15-496, 15-532 through 15-534.

320 Senate Hearings $305,306$.

${ }^{327}$ Op. cit., supra, note 323, Feb. 3, 1944, A-I8.
} 
introduced an omnibus termination bill ${ }^{328}$ which was the culmination of several months study by their committees, Section $6(\mathrm{~b})$ of which provided that

“. . any contracting agency may settle any termination claim under any war contract by agreement with the war contractor or by determination of the amount due on the claim without such agreement, or by any combination of these methods. Where any such settlement is made by agreement, it shall be final and conclusive and shall not be reopened ... except $(I)$ to the extent otherwise provided by the terms of the settlement; (2) for fraud; (3) uporr renegotiation to eliminate excessive profits under the Renegotiation Act, unless exempt or exempted thereunder; or (4) by mutual agreement."

\section{ConcLusion}

It will be recalled that certain ends were set forth at the beginning of this article as those which should be served by any termination provision and the policies and procedures which give that provision substance. It has been the purpose of this article to demonstrate that these ends are served by the various termination articles now used by the War Department and by the policies and procedures estab. lished for their application. The keystone of these is, of course, the negotiated settlement. Without it there can be no expeditious, equitable and final determination of the amounts due contractors whose contracts have been terminated. Undoubtedly, as more experience is acquired in the actual termination and settlement of contracts, changes will be made in the details of these policies and procedures; indeed, some changes may even have been made between the time this is written (February I944) and the time it is published. The work of the Joint Contract Termination Board, for example, will undoubtedly have a great effect on some of these policies. Nevertheless the essentials of these policies and procedures must remain if current production is to be maintained without the disruption which would be caused by uncertainty as to contractors' rights in the event of termination of any of their contracts, and if the post-war transition from production for war to production for peace is to be made easily, speedily and without injury to our economical and political stability.

${ }^{328}$ S. 17r8, 78th Cong., 2d Sess. (1944). 
APPENDIX A

\section{Uniform Termination Article for Fixed Price Supply Contracts}

Article ... Termination at the Option of the Government. (a) The performance of work under this contract may be terminated by the Government in accordance with this Article in whole, or from time to time in part, whenever the contracting officer shall determine any such termination is for the best interests of the Government. Termination of work hereunder shall be effected by delivery to the contractor of a Notice of. Termination specifying the extent to which performance of work under the contract shall be terminated, and the date upon which such termination shall become effective. If termination of work under this contract is simultaneous with, a part of, or in connection with, a general termination (I) of all or substantially all of a group or class of contracts made by the................ Department for the same product or for closely related products, or (2) of war contracts at, about the time of, or following, the cessation of the present hostilities, or any major part thereof, such termination shall only be made in accordance with the provisions of this Article, unless the contracting officer finds that the contractor is then in gross or wilful default under this contract.

(b) After receipt of a Notice of Termination and except as otherwise directed by the contracting officer, the contractor shall (I) terminate work under the contract on the date and to the extent specified in the Notice of Termination; (2) place no further orders or subcontracts for materials, services or facilities except as may be necessary for completion of such portions of the work under the contract as may not be terminated; (3) terminate all orders and subcontracts to the extent that they relate to the performance of any work terminated by the Notice of Termination; (4) assign to the Government, in the manner and to the extent directed by the contracting officer, all of the right, title and interest of the contractor under the orders or subcontracts so terminated; (5) settle all claims arising out of such termination of orders and subcontracts with the approval or ratification of the contracting officer to the extent that he may require; which approval or ratifcation shall be final for all the purposes of this Article; (6) transfer title and deliver to the Government in the manner, to the extent and at the times directed by the contracting officer (i) the fabricated or unfabricated parts, work in process, completed work, supplies and other material produced as a part of, or acquired in respect of the performance of, the work terminated in the Notice of Termination, and (ii) the plans, drawings, information and other property which, if the contract had been completed, would be required to be furnished to the Government; (7) use his best efforts to sell in the manner, to the extent, at the time, and at the price or prices directed or authorized by the contracting officer, any property of the types referred to in subdivision (6) of this paragraph provided, however, that the contractor (i) shall not be required to extend credit to any purchaser and (ii) may retain any such property at a price or prices approved by the contracting officer; (8) complete performance of such part of the work as shall not have been termi- 
nated by the Notice of Termination; and (9) take such action as may be necessary or as the contracting officer may direct for protection and preservation of the prop. erty, which is in the possession of the contractor and in which the Government has or may acquire an interest.

(c) The contractor and the contracting officer may agree upon the whole or any part of the amount or amounts to be paid to the contractor by reason of the total or partial termination of work pursuant to this Article, which amount or amounts may include a reasonable allowance for profit, and the Government shall pay the agreed amount or amounts. Nothing in paragraph (d) of this Article prescribing the amount to be paid to the contractor in the event of failure of the contractor and the contracting officer to agree upon the whole amount to be paid to the contractor by reason of the termination of work pursuant to this Article shall be deemed to limit, restrict or otherwise determine or affect the amount or amounts which may be agreed upon to be paid to the contractor pursuant to this para. graph (c).

(d) In the event of the failure of the contractor and contracting officer to agree as provided in paragraph (c) upon the whole amount to be paid to the contractor by reason of the termination of work pursuant to this Article, the Government, but without duplication of any amounts agreed upon in accordance with paragraph (c), shall pay to the contractor the following amounts:

(I) For completed articles delivered to and accepted by the Government (or sold or retained as provided in paragraph (b) (7) above) and not theretofore paid for, forthwith a sum equivalent to the aggregate price for such articles computed in accordance with the price or prices specified in the contract;

(2) In respect of the contract work terminated as permitted by this Article the total (without duplication of any item) of (i) the cost of such work exclusive of any cost attributable to articles paid or to be paid for under paragraph (d) (r) hereof; (ii) the cost of settling and paying claims arising out of the termination of work under subcontracts or orders as provided in paragraph (b) (5) above, exclusive of the amounts paid or payable on account of supplies or materials delivered or services furnished by the subcontractor prior to the effective date of the notice of termination of work under this contract, which amounts shall be included in the cost on account of which payment is made under subdivision (i) above; and (iii) a sum equal to .......\%* of the part of the amount determined under subdivision (i) which represents the cost of articles or materials not processed by the contractor, plus a sum equal to .......\%** of the remainder of such amount, but the aggregate of such sums shall not exceed $6 \%$ of the whole of the amount determined under subdivision (i), which for the purpose of this subdivision (iii) shall exclude any charges for interest on borrowing;

(3) The reasonable cost of the preservation and protection of property incurred pursuant to paragraph (b) (9) hereof; and any other reasonable cost'inci-

- Not to exceed $2 \%$.

* To be established at a figure which is fair and reasonable under the circumstances. 
dental to termination of work under this contract, including expense incidental to the determination of the amount due to the contractor as the result of the termination of work under this contract.

The total sum to be paid to the contractor under subdivision ( $I$ ) and (2) of this paragraph (d) shall not exceed the total contract price reduced by the amount of payments otherwise made and by the Contract price of work not terminated. Except for normal spoilage and to the extent that the Government shall have otherwise expressly assumed the risk of loss, there shall be excluded from the amounts payable to the contractor as provided in paragraph (d) (I) and paragraph (d) (2) (i), all amounts allocable to or payable in respect of property, which is destroyed, lost, stolen or damaged so as to become undeliverable prior to the transfer of title to the Government or to a buyer pursuant to paragraph (b) (7) or prior to the 6oth day after delivery to the Government of an inventory covering such property, whichever shall first occur.

(e) The obligation of the Government to make any payments under this article: (I) shall be subject to deductions in respect of (i) all unliquidated partial or progress payments, payments on account theretofore made to the contractor and unliquidated advance payments; (ii) any claim which the Government may have against the contractor in connection with this contract, and (iii) the price agreed upon or the proceeds of sale of any materials, supplies or other things retained by the contractor or sold, and not otherwise recovered by or credited to the Government, and (2) in the discretion of the contracting officer shall be subject to deduction in respect of the amount of any claim of any subcontractor or supplier whose subcontract or order shall have been terminated as provided in paragraph (b) (3) except to the extent that such claim covers (i) property or materials delivered to the contractor or (ii) services furnished to the contractor in connection with the production of completed articles under this contract.

(f) In the event that, prior to the determination of the final amount to be paid to the contractor as in this article provided, the contractor shall file with the-contracting officer a request in writing that an equitable adjustment should be made in the price or prices specified in the contract for the work not terminated by the Notice of Termination, the appropriate fair and reasonable adjustment shall be made in such price or prices.

(g) The Government shall make partial payments and payments on account, from time to time, of the amounts to which the contractor shall be entitled under this Article, whether determined by agreement or otherwise, whenever in the opinion of the contracting officer the aggregate of such payments shall be within the amount to which the contractor will be entitled hereunder.

(h) For the purposes of paragraphs (d) (2) and (d) (3) hereof, the amounts of the payments to be made by the Government to the contractor shall be determined in accordance with the Statement of Principles for Determination of Costs upon Termination of Government Fixed Price Supply Contracts approved by the Joint 
Contract Termination Board, December 3I, I943. The contractor for a period of three years after final settlement under the contract shall make available to the Government at all reasonable times at the office of the contractor all of its books, records, documents, and other evidence bearing on the costs and expenses of the conitractor under the contract and in respect of the termination of work thereunder.

\section{APPENDIX B}

\section{Statement of Principles for Determination of Costs Upon Termination of Government Fixed Price oSupply Contracts}

I. General Principles. The costs contemplated by this Statement of Principles are those sanctioned by recognized commercial accounting practices and are intended to include the direct and indirect manufacturing, selling and distribution, administrative and other costs incurred which are reasonably necessary for the performance of the contract, and are properly allocable or apportionable, under such practices, to the contract (or the part thereof under consideration). The general principles set out in this Statement are subject to the application of any special provisions of the contract. Certain costs are specifically described below because of their particular significance, and, as in the case of other costs, should be included to the extent that they are allocable to or should be apportioned to the contract or the part thereof under consideration.

(a) Common Inventory. The costs of items of inventory which are common to the contract and to other work of the contractor.

(b) Common Claims of Subcontractors. The claims of subcontractors which are common to the contract and to other work of the contractor.

(c) Depreciation. An allowance for depreciation at appropriate rates on buildings, machinery and equipment and other facilities including such amounts for obsolescence due to progress in the arts and other factors as are ordinarily given consideration in determining depreciation rates. Depreciation as defined herein shall not include loss of useful value of the type covered by subparagraph (f).

(d) Experimental and Research Expense. General experimental and research expense to the extent consistent with an established pre-war program, or to the extent related to war purposes.

(e) Engineering and Development and Special Tooling. Costs of engineering and development and of special tooling; provided that the contractor protects any interests of the Government by transfer of title or by other means deemed appropriate by the Government.

(f) Loss on facilities-Conditions on Allowance. In the case of any special facility acquired by the contractor solely for the performance of the contract, or the contract and other war production contracts, if upon termination of the contract such facility is not reasonably capable of use in the other business of the contractor having regard to the then condition and location of such facility, an amount which bears the same proportion to the loss of useful value as the deliveries not made 
under the contract bear to the total of the deliveries which have been made and would have been made had the contract and the other contracts been completed, provided that the amount to be allowed under this paragraph shall not exceed the adjusted basis of the facility for Federal income tax purposes immediately prior to the date of the termination of the contract, and provided further that no amount shall be allowed under this paragraph unless upon termination of the contract title to the facility is transferred to the Government, except where the Government elects to take other appropriate means to protect its interests.

(g) Special Leases. (I) Rentals under leases clearly shown to have been made for the performance of the contract, or the contract and other war production contracts, covering the period necessary for complete performance of the contract and such further period as may have been reasonably necessary; (2) costs of reasonable alteration of such leased property made for the same purpose; and (3) costs of restoring the premises, to the extent required by reasonable provisions of the lease; less (4) the residual value of the lease; provided that the contractor shall have made reasonable efforts to terminate, assign, or settle such leases or otherwise reduce the cost thereof.

(h) Advertising. Advertising expense to the extent consistent with a pre-war program or to the extent reasonable under the circumstances.

(i) Limitation on Costs Described in Subparagraphs $(d),(e),(f),(g)$, and $(h)$. In no event shall the aggregate of the amounts allowed under subparagraphs (d), $(\mathrm{e}),(\mathrm{f}),(\mathrm{g})$, and (h) exceed the amount which would have been available from the contract price to cover these items, if the contract had been completed, after considering all other costs which would have been required to complete it.

(j) Interest. Interest on borrowings.

(k) Settlement expenses. Reasonable accounting, legal, clerical and other expenses necessary in connection with the termination and settlement of the contract and subcontracts and purchase orders thereunder, including expenses incurred for the purpose of obtaining payment from the Government only to the extent reasonably necessary for the preparation and presentation of settlement proposals and cost evidence in connection therewith.

(1) Protection and Disposition of Property. Storage, transportation and other costs incurred for the protection of property acquired or produced for the contract or in connection with the disposition of such property.

2. Initial Costs. Costs of a non-recurring nature which arise from unfamiliarity with the product in the initial stages of production should be appropriately apportioned between the completed and the terminated portions of the contract. In this category would be included high direct labor and overhead costs, including training, costs of excessive rejections and similar items.

3. Excluded Costs. Without affecting the generality of the foregoing provisions in other respects, amounts representing the following should not be included as elements of cost: 
(a) Losses on other contracts, or from sales or exchanges of capital assets; fees and other expenses in connection with reorganization or recapitalization, anti-trust or federal income-tax litigation, or prosecution of federal income tax claims or other claims against the Government (except as provided in paragraph $1(\mathrm{k})$ ); losses on investments; provisions for contingencies; and premiums on life insurance where the contractor is the beneficiary.

(b) The expense of conversion of the contractor's facilities to uses other than the performance of the contract.

(c) Expenses due to the negligence or wilful failure of the contractor to discontinue with reasonable promptness the incurring of expenses after the effective date of the termination notice.

(d) Costs incurred in respect to facilities, materials or services purchased or work done in "excess of the reasonable quantitative requirements of the entire contract.

(e) Costs which, as evidenced by accounting statements submitted in renegotiation under Section 403 of the Sixth Supplemental National Defense Appropriation Act, I942, as amended, were charged off during a period covered by a previous renegotiation, may not be subsequently included in the termination settlement if a refund was made for such period, or to the extent that such charging off is shown to have avoided such refund.

4. To the extent that they conform to recognized commercial accounting practices and the foregoing Statement of Principles, the established accounting practices of the contractor as indicated by his books of account and financial reports will be given due consideration in the preparation of statements of cost for the purposes of this, article.

5. The failure specifically to mention in this statement any item of cost is not intended to imply that it should be included or excluded.

\section{APPENDIX C}

Article............ Termination for the Convenience of the Government. (a) The Government may, at any time, terminate this contract in whole or in part by a notice in writing from the contracting officer to the contractor that the contract is terminated under this Article. Such termination shall be effective in the manner and upon the date specified in said notice and shall be without prejudice to any claims which the Government may have against the contractor, or any claims which the contractor may have against the Government. Upon receipt of such notice the contractor shall, except as the contracting officer directs otherwise, (I) discontinue all work and the placing of all orders for materials and facilities in connection with performance of this contract, cancel all existing orders chargeable to this contract, and terminate all subcontracts chargeable to this contract; (2) transfer to the Government, by delivery, f.o.b.............. or by such other means as the contracting officer may direct, title to all completed supplies (including spare parts, drawings, information, and other things) called for herein, not previously 
delivered, and partially completed supplies, work in process, materials, fabricated parts, plans, drawings, and information acquired or produced by the contractor for the performance of this contract; and (3) take such action as may be necessary to secure to the Government the benefits of any rights remaining in the contractor under orders or subcontracts wholly or partially chargeable to this contract to the extent that such orders or subcontracts are so chargeable. If and as the contracting officer so directs or authorizes, the contractor shall sell at a price approved by the contracting officer, or retain at a price mutually agreeable; any such supplies, partially completed supplies, work in process, materials, fabricated parts or other things. The proceeds of such sale or the agreed price shall be paid or credited to the Government in such manner as the contracting officer may direct so as to reduce the amount payable by the Government under this Article.

(b) The Government shall, upon such termination of this contract, pay to the contractor the contract price of all supplies (including spare parts, drawings, information, and other things) called for herein which have been completed in accordance with the provisions of this contract and to which title has been received by the Government under the provisions of paragraph (a) (2) of this Article and for which payment has not previously been made.

(c) In addition to, and without duplication of, the payments provided for in paragraph (b), or of payments made prior to the termination of this contract, the Government shall pay to the contractor such sum as the contracting officer and the contractor may agree by supplemental âgreement is reasonably necessary to com. pensate the contractor for his costs, expenditures, liabilities, commitments, and work in respect to the uncompleted portion of the contract so far as terminated by the notice referred to in paragraph (a). The contracting officer shall include in such sum such allowance for anticipated profit with respect to such uncompleted portion of the contract as is reasonable under all the circumstances.

(d) If the contracting officer and the contractor, within ninety days from the effective date of the notice of termination referred to in paragraph (a) or within such extended period as may be agreed upon between them, cannot agree upon the sum payable under the provisions of paragraph (c), the Government, without duplication of any payment made pursuant to paragraph (b) or prior to the termination of this contract, shall in the above events compensate the contractor for the uncompleted portion of the contract as.follows:

(I) By reimbursing the contractor for all actual expenditures and costs certified by the contracting officer as having been made or incurred with respect to the uncompleted portion of the contract;

(2) By reimbursing, or providing for the payment or reimbursement of, the contractor for all expenditures made and costs incurred with the prior written approval of the contracting officer in settling or discharging that portion of the outstanding obligations or commitments of the contractor which had been incurred or entered into with respect to the uncompleted portion of the contract; and 
(3) By paying the contractor, as a profit on the uncompleted portign of the contract in so far as a profit is realized hereunder, a sum to be computed by the contracting officer in the following manner: (A) The contracting officer shall estimate the profit which would have been realized on the uncompleted portion of the contract if the contract had been completed and labor and material costs prevailing at the date of termination had remained in effect; (B) Estimate, from a consideration of all relevant factors, the percentage of completion of the uncompleted portion of the contract; (C) Multiply the anticipated profit determined under (A) by the percentage determined under (B). The result is the amount to be paid to the contractor as a proportionate share of profit, if any, as above provided.

Notwithstanding the above provisions, no compensation shall be paid under this paragraph (d) by way of reimbursement for expenditures, including expenditures made in settling or discharging obligations or commitments, or by way of profit on account of supplies and other things which are undeliverable because of destruction or damage, whether or not because of the fault of the contractor.

(e) The Government shall pay to the contractor such sum as the contracting officer and the contractor may agree upon for expenditures made and costs incurred with the approval of the contracting officer (a) after the date of termination for the protection of Government property; and (b) for such other expenditures and costs as may be necessary in connection with the settlement of this contract, and in the absence of such agreement as to the amount of such expenditures and costs shall reimburse the Contractor for the same.

(f) The obligation of the Government to make any of the payments required by this Article shall be subject to any unsettled claim for labor or material and to any claim which the Government may have against the Contractor under or in connection with this contract, and payments under this Article shall be subject to reasonable deductions by the Contracting Officer on account of defects in materials or workmanship.

(g) The sum of all amounts payable under this Article, plus the sum of all amounts previously paid under this contract, shall not exceed the total contract price, adjusted in the event that this contract contains an article providing for price adjustment, on the basis of the estimate of the Contracting Officer, to the extent which would have been required by such article if this contract had been completed and labor and materials costs prevailing at the date of termination had remained in effect.

(h) Should the above provisions of this Article not result in payment to the Contractor of at least $\$ 100$, then that amount shall be paid to the Contractor in lieu of any and all payments hereinbefore provided for in this Article.

(i) The Government shall promptly make partial payments to the Contractor (I) on account of the amounts due under paragraphs (c), (d) and (e) of this Article to the extent that, in the judgment of the Contracting Officer, such payments'are clearly within the amounts due under such paragraphs, and 
(2) of such amounts as the Contracting Officer may direct, an account of proposed settlements of outstanding obligations or commitments, to be made by the Contractor pursuant to paragraph (d) (2) of this Article, if such settlements shall have been approved by the Contracting Officer and subject to such provisions for escrow or direct payment to the persons entitled to receive settlement payments as the Contracting Officer may require.

(j) Any disputes arising out of termination under this Article shall be decided in accordance with the procedure prescribed in Article..... of this contract.

(k) Upon the making of the payments called for by this Article, all obligations of the Government to make further payments or to carry out other undertakings hereunder shall cease forthwith and forever, except that all rights and obligations of the respective parties under the Articles, if any, of this contract applicable to patent infringements and reproduction rights shall remain in full force and effect.

(1) The Government shall terminate this contract only in accordance with this Article, except as otherwise provided by law or by Article..... (DelaysDamages). Notwithstanding Article..... (Delays-Damages) and any defaults of the Contractor, the Government shall terminate this contract only in accordance with this Article if such termination is simultaneous with or part of or in connection with a general termination of war contracts at about the time of, or following the cessation of the present hostilities or the end of the present war, unless the Contracting Officer finds that the defaults of the Contractor (I) have been gross or wilful and (2) have caused substantial damage to the Government. 